\title{
Distribution, Habitat, and Zoogeography of the Semifossorial Red-bellied Snake Storeria occipitomaculata (Storer) in Illinois
}

Lauren E. Brown and Christopher A. Phillips 
Prairie Research Institute

William Shilts, Executive Director

Illinois Natural History Survey

Brian D. Anderson, Director

Forbes Natural History Building

1816 South Oak Street

Champaign, Illinois 61820

217-333-6880

Citation:

Brown, L.E., and C.A. Phillips. 2012. Distribution, habitat, and zoogeography of the semifossorial red-bellied snake Storeria occipitomaculata (Storer) in Illinois. Illinois Natural History Survey Bulletin 39(5):297-322.

The Authors:

Lauren E. Brown is Emeritus Professor of Vertebrate Zoology and Curator of Amphibians and Reptiles, School of Biological Sciences, Illinois State University, Campus Box 4120, Normal 61790-4120. He is also a Research Affiliate with the Illinois Natural History Survey, and Associate in Zoology, Field Museum, Chicago. Christopher A. Phillips is Associate Research Program Leader and Curator of Amphibians and Reptiles, Illinois Natural History Survey, 1816 S. Oak St., Champaign 61820. He is also Affiliate Associate Professor of Animal Biology and Animal Science, University of Illinois, Urbana-Champaign.

For permissions: contact the Prairie Research Institute.

Editor: Charles Warwick

US ISSN 0073-4918

US ISBN 1-882932-28-5

$\mathrm{P} 0601537-.45 \mathrm{M}-04 / 2012$

(C) 2012 University of Illinois Board of Trustees. All rights reserved.

Printed with soy ink on recycled and recyclable paper.

The University of Illinois will not engage in discrimination or harassment against any person because of race, color, religion, national origin, ancestry, age, marital status, disability, sexual orientation including gender identity, unfavorable discharge from the military or status as a protected veteran and will comply with all federal and state nondiscrimination, equal opportunity and affirmative action laws, orders and regulations. This nondiscrimination policy applies to admissions, employment, access to and treatment in University programs and activities.

University complaint and grievance procedures provide employees and students with the means for the resolution of complaints that allege a violation of this Statement. Inquiries or complaints may be addressed to the Director and Assistant Chancellor, Office of Equal Opportunity and Access, 601 East John Street, Swanlund Administration Building, (217) 333-0885, fax (217) 244-9136, TTY (217) 244-9850 or the Associate Provost and Director, Academic Human Resources, Henry Administration Building, (217) 333-6747, fax (217) 244-5584. For other University of Illinois information, contact University Directory Assistance at 333-1000. 


\section{Distribution, Habitat, and Zoogeography of the Semifossorial Red-bellied Snake Storeria occipitomaculata (Storer) in Illinois}

Lauren E. Brown and Chistopher A. Phillips 


\section{Distribution, Habitat, and Zoogeography of the Semifossorial Red-bellied Snake Storeria occipitomaculata (Storer) in Illinois}

Lauren E. Brown and Chistopher A. Phillips

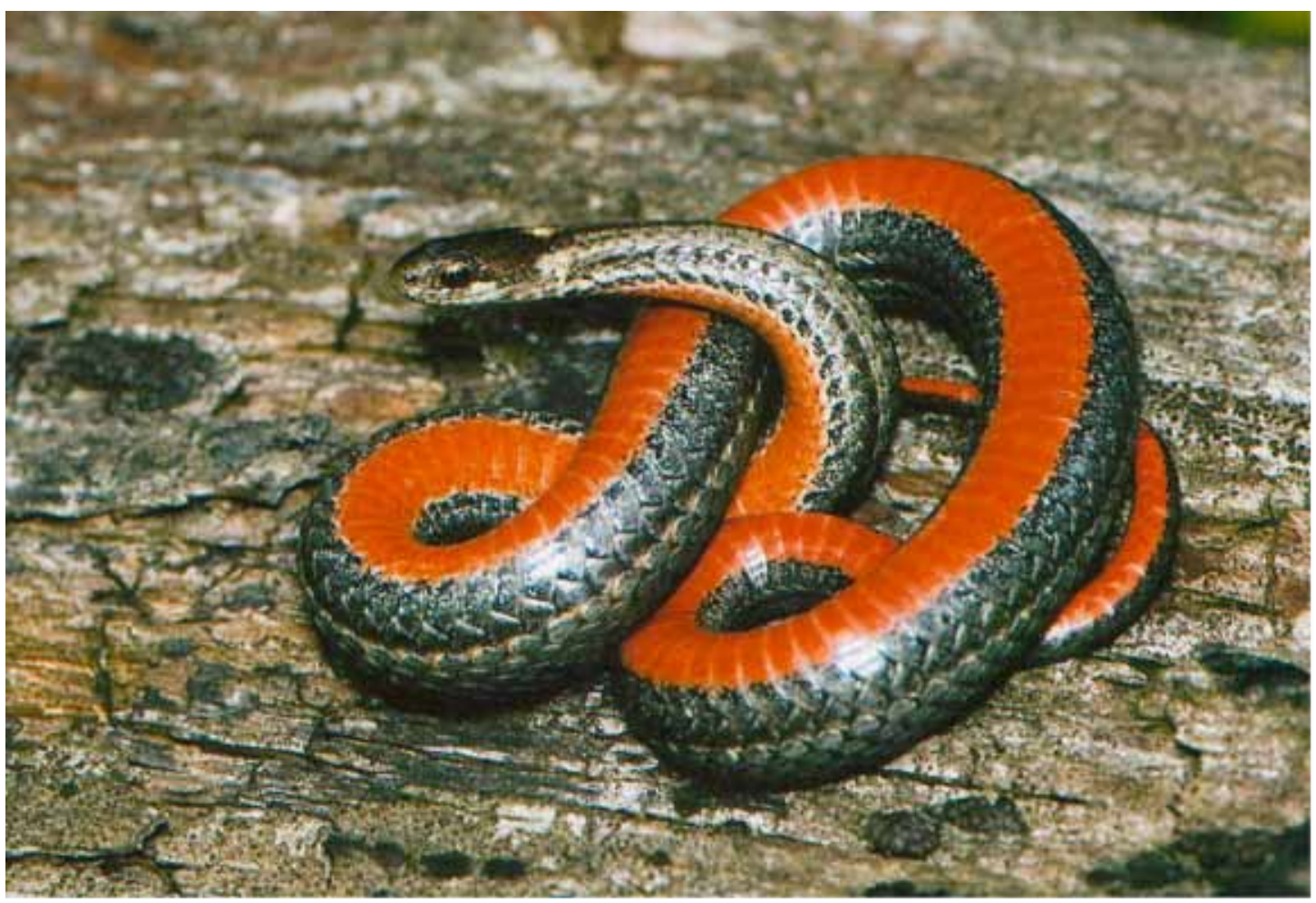

Figure 1. Living red-bellied snake, Storeria occipitomaculata showing vivid red ventral coloration. This specimen was from Somme Prairie, Cook County, Illinois. Photo by M. Ignoffo. 


\section{CONTENTS}

Frontis (Figure 1: living red-bellied snake) ............................................iii

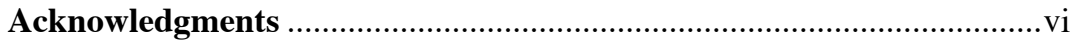

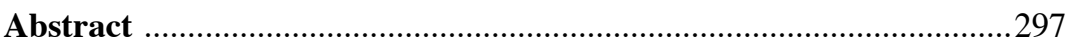

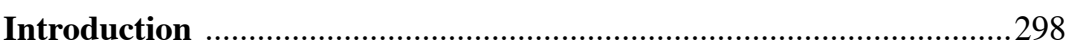

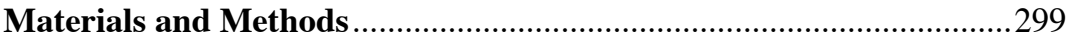

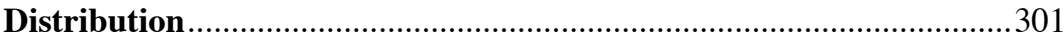

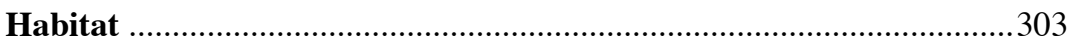

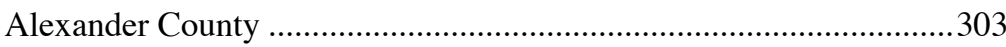

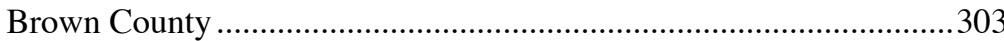

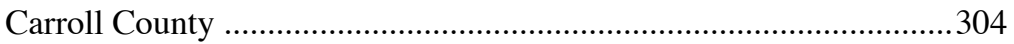

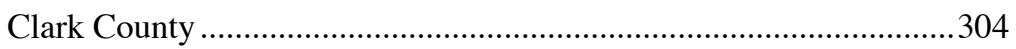

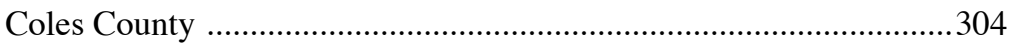

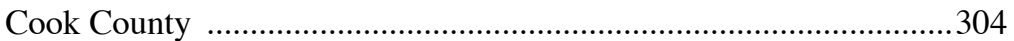

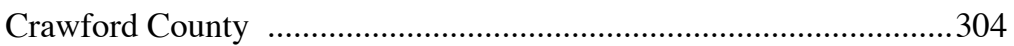

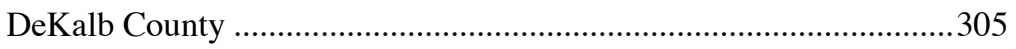

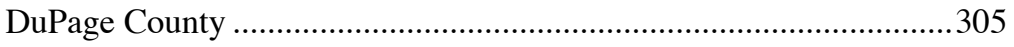

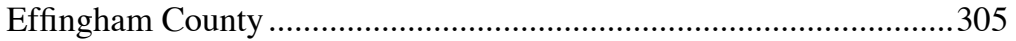

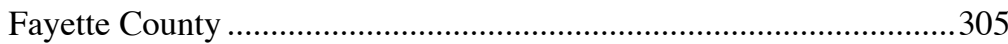

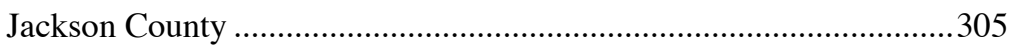

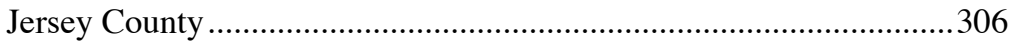

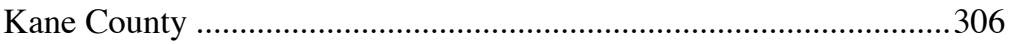

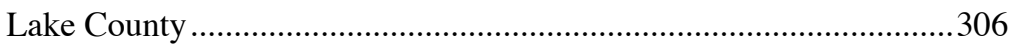

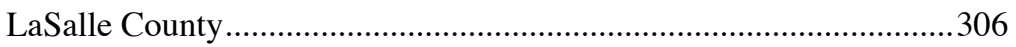

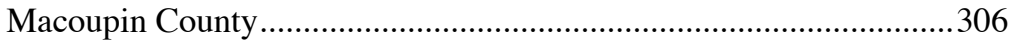

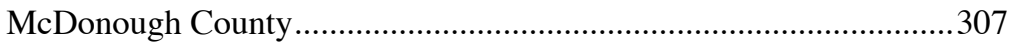




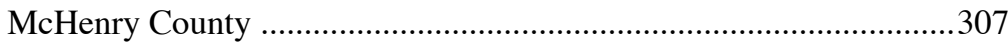

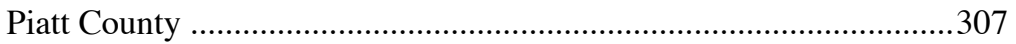

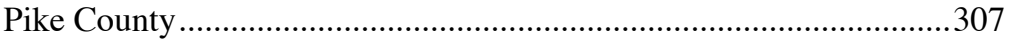

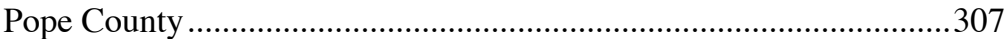

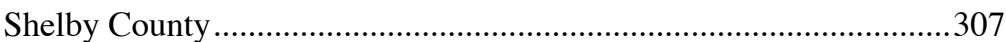

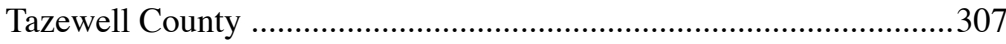

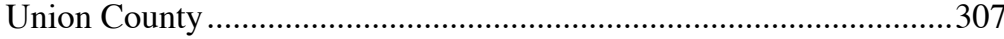

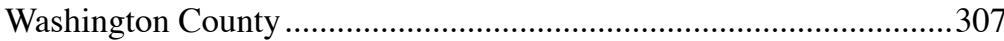

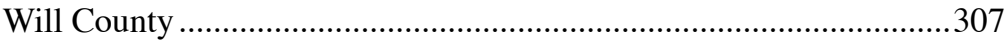

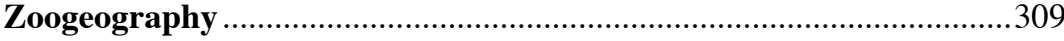

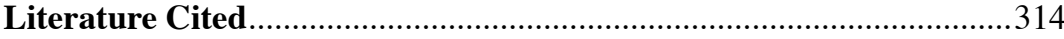

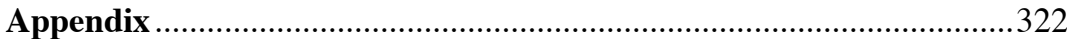




\section{ACKNOWLEDGMENTS}

We thank the following institutions for allowing us to visit their facilities to examine specimens or providing loans: American Museum of Natural History; Chicago Academy of Sciences; Cornell University, Museum of Vertebrates; Eastern Illinois University; Field Museum; Harvard University, Museum of Comparative Zoology; Illinois State Museum; Louisiana State University, Museum of Natural Science; University of Michigan, Museum of Zoology; Northern Illinois University; Principia College; National Museum of Natural History; Southern Illinois University at Carbondale; Texas A\&M University, Texas Cooperative Wildlife Collection.

We thank: Evan Brown for recording data during examination of specimens at the Chicago Academy of Sciences; Jill Thomas for cartography (Figs. 4, 5, 8); Edward Mockford for drawing Fig. 2; Matthew Ignoffo for providing Figs. 1 and 7; Michael Dreslik for providing Fig. 6; Tak Cheung for providing Fig. 3 and electronically preparing all figures for publication; Jill Brown for help with map work; John Kostelnick for help with Arc GIS and preparing Fig. 9; Meredith Mahoney for clarifying the status of ISM 688486; Tari Tweddale for providing GIS Data Layer, Version 6 of Land Cover of Illinois in the Early 1800s, which facilitated preparation of Fig. 9; William Evans, Editor, American Midland Naturalist, for granting permission to use part of a map that originally appeared in Am. Midl. Nat. 31:20 for preparation of Fig. 8; Diane Szafoni for permission to use GIS Data Layer, Version 6 of Land Cover of Illinois... for preparation of Fig. 9; Thomas Anton, Ronald Brandon, Frank DeSerto, Carl Ernst, Matthew Ignoffo, Richard King, Michael Lannoo, David Mauger, Don Moll, Stephen Mullin, Michael Redmer, and Alan Resetar for providing detailed information on distribution and habitat for publication; Anne Brown Nash, Susan Oslund, and Marilyn Prochnow for showing us S. occipitomaculata they collected; Jill Brown, Edward Mockford, Robert Nelson, and Donald Shepard for critically reading the ms.; Sally Little and Cheryl Hickey for typing the ms. Craig Gatto and Scott Sakaluk (Illinois State University) for providing publication funds; Don Moll, Michael Lannoo, and Jeff Levengood for reviewing the manuscript. 


\begin{abstract}
The examination of 387 preserved red-bellied snakes, Storeria occipitomaculata, from 18 museums and collections, literature records, and unpublished records revealed distributional records throughout much of Illinois, in contrast to earlier studies which found a more limited distribution. Seventy-one records of habitat types from museum records, field notes, and literature indicated that the species occupies woodlands but is not primarily forest adapted. It also inhabits prairie and prairielike habitats in Illinois. The common occurrence of this species in this type of habitat has not heretofore been reported elsewhere in the range of the snake. Our findings do not support an older zoogeographic theory that assumed the snake was nonadapted for prairie and thus excluded from the Prairie Peninsula. We propose that the species was able to occupy the area near the ice rim of the Wisconsin Episode glaciation, and followed the glaciation as it retreated because of the snake's cold tolerance, ability to inhabit northern prairies and coniferous forests, vivipary which allows thermoregulation by gravid females, and the relatively temperate climate along the glacial rim. Within recent times, it seems likely that the snake was extirpated throughout much of the former prairie by destructive changes associated with agriculture.
\end{abstract}




\section{Introduction}

The zoology of the red-bellied snake Storeria occipitomaculata (Storer 1839) is poorly known, which is typical for a number of small, secretive snakes in North America. The most striking characteristic of this snake is its brilliant red belly (Fig. 1), although some may be orange. Maximum total length attained is $40.6 \mathrm{~cm}$, but most specimens are $21-27 \mathrm{~cm}$ (Ernst 2002). The species is distributed in much of the eastern half of North America with outer range limits from southeastern Texas, east to central Florida, north along the eastern seaboard to Cape Breton Island in northeastern Nova Scotia, Canada, west through southern Canada to its most northern distribution west of Lake Winnipeg in Manitoba, southwest to southeastern Saskatchewan, south to central North Dakota, and south through the eastern Great Plains to southeastern Texas (Ernst 2002). Records are lacking for a large area primarily in Mississippi and northwestern Alabama devoted mostly to agriculture, and prior to this study, much of the Prairie Peninsula from Iowa and Missouri east to central Ohio. Relictual populations occur at a number of locations in the Great Plains, most notably in the Black Hills (Smith 1963; Ernst 2002).

Prior to this study, the habitat of $S$. occipitomaculata was widely considered to be woodland (e.g., Schmidt and Davis 1941), but the species has been found in a variety of habitats (Wright and Wright 1957). In Illinois, $60 \%$ of the state was originally prairie during presettlement times (Robertson et. al 1997) and S. occipitomaculata has been found at a number of localities (Smith 1961), but specific details on habitat have been published for few localities in Illinois.

It has long been recognized that there was often an association of the snake with a mesic environment (e.g., Pope 1964). However, S. occipitomaculata has been found at dry localities (e.g., Wright and Wright 1957), and Ernst and Ernst (2003) indicated that more xeric habitats are utilized by north-central populations. Furthermore, in Illinois it has survived the frequent annual droughts from mid-summer to early fall, as well as the severe, prolonged droughts that were widespread in the state in the late 1980s through the early 1990s, and presumably during the 1930s. Many authors have indicated that S. occipitomaculata is fossorial (e.g., Conant 1957), and there have been a number of reports of the species in subterranean hibernacula (Criddle 1937; Lachner 1942; Carpenter 1953; Bothner 1963; Lang 1969, 1981). However, we found no papers describing burrowing behavior or subterranean location of the snake during spring and summer.

Blanchard (1937) marked and released 150+ specimens from 1925-1936 in Michigan. There were two individuals recaptured in the same year of initial capture, but no snakes were ever recaptured in subsequent years. Blanchard (1937) indicated that the low recapture rate might be due to the "wandering propensities" of the snake as well as unrestricted habitat and "hiding places." Semlitsch and Moran (1984) marked a total of 61 specimens at three locations in South Carolina with recapture percentages of $3 \%$ ( 1 of 34 ), $9 \%$ ( 1 of 11 ), and $13 \%$ (2 of 16). Semlitsch and Moran (1984) interpreted their data as indicating large population size or rapid turnover. Gregory (1977) marked 22 in Manitoba, Canada but none was recaptured. Such extremely low recaptures also suggest that marked snakes removed themselves from the sampling pool (e.g., retreated underground or moved out of the sampling area on the surface). The repeated use of the term "secretive" by many writers (e.g., Conant and Collins 1998) in describing the snake supports this suggestion.

The last comprehensive distributional study of S. occipitomaculata with detailed mapping of each locality in Illinois was published 50 years ago (Smith 1961). Since that time, there have been a field guide (Phillips et al. 1999) published with county records plotted and a number of short papers published (Klimstra and Hutchison 1965; Munyer and Parmalee 1967; Applegate and Zimbleman 1978; Cochran 1989; Ludwig et al. 1990; Sliwinksi 1990; Burbrink and Wilson 1994; 
Tucker et al. 1994; Redmer and Ballard 1995; Bryant 1999; Wilson 1999; Bittner and Bittner 2001; Walley 2001; Andre and Walley 2002; Foster and Hampton 2003; Foster and Mullin 2007; Petzing et al. 2007; Wodika 2008; Petzing et al. 2009) reporting new locality records, as well as many specimens deposited in museums throughout the state. An older monograph (Trapido 1944) discussed the zoogeography of the species based in part on the limited distribution data then available for Illinois. With the additional distributional data now available, Trapido's (1944) zoogeographic conclusion is outdated. Consequently, given the inconsistencies heretofore discussed, we carried out a detailed study of the distribution, habitat, and zoogeography of S. occipitomaculata in Illinois.

\section{Materials and Methods}

An intensive literature search was carried out on the zoology of S. occipitomaculata (emphasizing distribution, ecology, and zoogeography) following the methodology of Brown et al. (2008). Initially two search engines, Google Scholar (Advanced Scholar Search) and JSTOR Advanced Search were used, followed by an in-depth traditional library search. The literature survey by Ernst (2002) was particularly helpful for the latter.

This research involved extensive examination of preserved museum specimens of S. occipitomaculata. The species can be identified by four diagnostic characters: (1) deep red or orange ventral coloration (Fig. 1); (2) three light spots immediately posterior to the head, one dorsal, one on each side (Fig. 1); (3) two (occasionally more) preocular scales anterior to each orbit (Fig. 2); (4) a light spot of variable size on each fifth supralabial scale

(Figs. 1, 2; Trapido 1944; Smith 1961). No other snake species in Illinois or eastern North America has this combination of characteristics. The red or orange ventral coloration fades quickly after preservation, and cannot be used to identify museum specimens. Trapido (1944) and others mentioned that the three post-cranial spots sometimes fuse to form a light bar across the neck. (This is a diagnostic characteristic in the Florida redbellied snake $S$. occipitomaculata obscura Trapido 1944 of the southern and southeastern U.S.) In Illinois we found this condition in $<5 \%$ of the specimens. Expansions in the bar usually occur at the normal location of the spots (Fig. 3). Sometimes only two spots (dorsal and one lateral) are connected by a bar. A similar postcranial ring occurs in the ring-necked snake, Diadophis punctatus (which is also found in Illinois, Smith 1961; Phillips et al. 1999), but the ring does not have enlarged areas. Diadophis punctatus has $2+2$ preoculars like $S$. occipitomaculata, but has smooth dorsal scales in contrast to $S$. occipitomaculata, which has keeled dorsal scales (Smith 1961; Phillips et al. 1999). Young of DeKay's brownsnake Storeria dekayi, a species widespread in Illinois, also have a small light collar behind the head (Trapido 1944; Smith 1961; Phillips et al. 


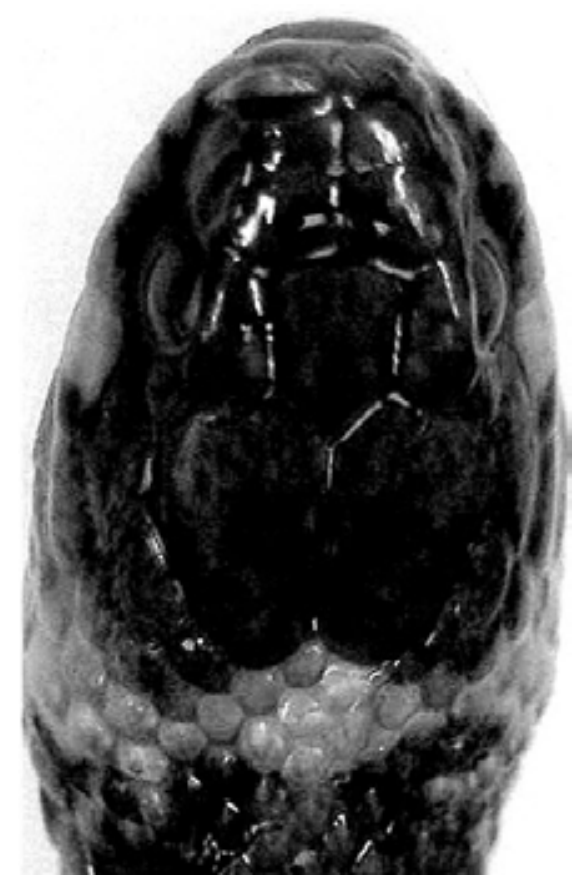

Figure 3. Dorsal view of head and neck of a preserved red-bellied snake, Storeria occipitomaculata, INHS 7839, Horseshoe Lake, Alexander County, Illinois. This individual is an infrequently encountered $(<5 \%)$ variant that shows linkage of the three postcranial spots into a bar, which is enlarged at the normal location of the spots. Photo by H. Tak Cheung.

1999). However, S. dekayi almost always has $1+1$ peroculars (Trapido 1944; Smith 1961; Phillips et al. 1999).

All specimens were examined in detail for diagnostic characters under a dissecting microscope (Bausch and Lomb zoom lens) from $10.5-45$ power. The heads of some specimens were severely damaged as a result of being run over by vehicles on roads or deliberately killed by humans. This often resulted in major shifting of the skull bones and scales, which necessitated detailed examination with dissecting probes (however, no tissue was cut or removed).
The sources of locality data in addition to museum records (printouts of catalog entries, specimen labels) were our field notes as well as those of several competent herpetologists (pers. comm. T. Anton, R. Brandon, M. Ignoffo, R. King, D. Mauger, S. Mullin, M. Redmer), and literature records (those mentioned previously as well as Garman 1892, Weed 1922, Schmidt and Necker 1935, Cagle 1942, Peters 1942, Minton and Minton 1948, Stille and Edgren 1948, and Stein 1954). Many of the literature records were based on newly deposited museum specimens, which we also examined. Four earlier publications (Trapido 1944; Smith 1961; Phillips et al. 1999; Ernst 2002) presented distribution maps based on museum specimens and literature records. Their localities are based on some of the specimens and literature records we examined.

Information on habitats was obtained from catalog entries (Field Museum, Southern Illinois University at Carbondale, Illinois Natural History Survey), specimen labels, field notes mentioned previously, and literature descriptions.

Prior to the preparation of Phillips et al. (1999), the primary author wrote 37 natural history museums throughout the country requesting records of their specimens of species of reptiles and amphibians collected in Illinois. The resulting museum lists, plus those of several additional museums and collections contacted by L. Brown, provided the baseline for our initiation of loans. In total, 387 specimens of $S$. occipitomaculata were examined from 18 museums and collections.

We used symbolic museum codes (Sabaj Pérez 2010) as follows: AMNH (American Museum of Natural History), CA (Chicago Academy of Sciences), CU (Cornell University Museum of Vertebrates), FMNH (Field Museum), INHS (Illinois Natural History Survey), LSUMZ (Louisiana Museum of Natural Science), MCZ (Museum of Comparative Zoology, Harvard University), SIUC (Southern Illinois University at Carbondale), TCWC (Texas Cooperative Wildlife Collection, Texas A\&M University), UIMNH (University of Illinois Natural History 
Museum), UMMZ

(University of Michigan

Museum of Zoology), and USNM (National

Museum of Natural

History). Specimens

were also examined

from collections not

listed in Sabaj Pérez

(2010). Abbreviations

used were: CA-NU

(Chicago Academy of

Sciences-Northwestern

University Museum, specimens entered into the CA catalog using the original numbers from Northwestern University Museum), EIU (Eastern Illinois University), HDW-NIU (Harlan D. Walley-Northern Illinois University), ISM (Illinois State Museum), ISUC (Illinois State University Collections), and PC (Principia College). Specimens examined are listed in the Appendix.

\section{Distribution}

Since the first report of S. occipitomaculata in Illinois by Kennicot (1855) from Cook County, there have been numerous records published and specimens collected from many areas of the state. The distribution of known locality records for $S$. occipitomaculata in

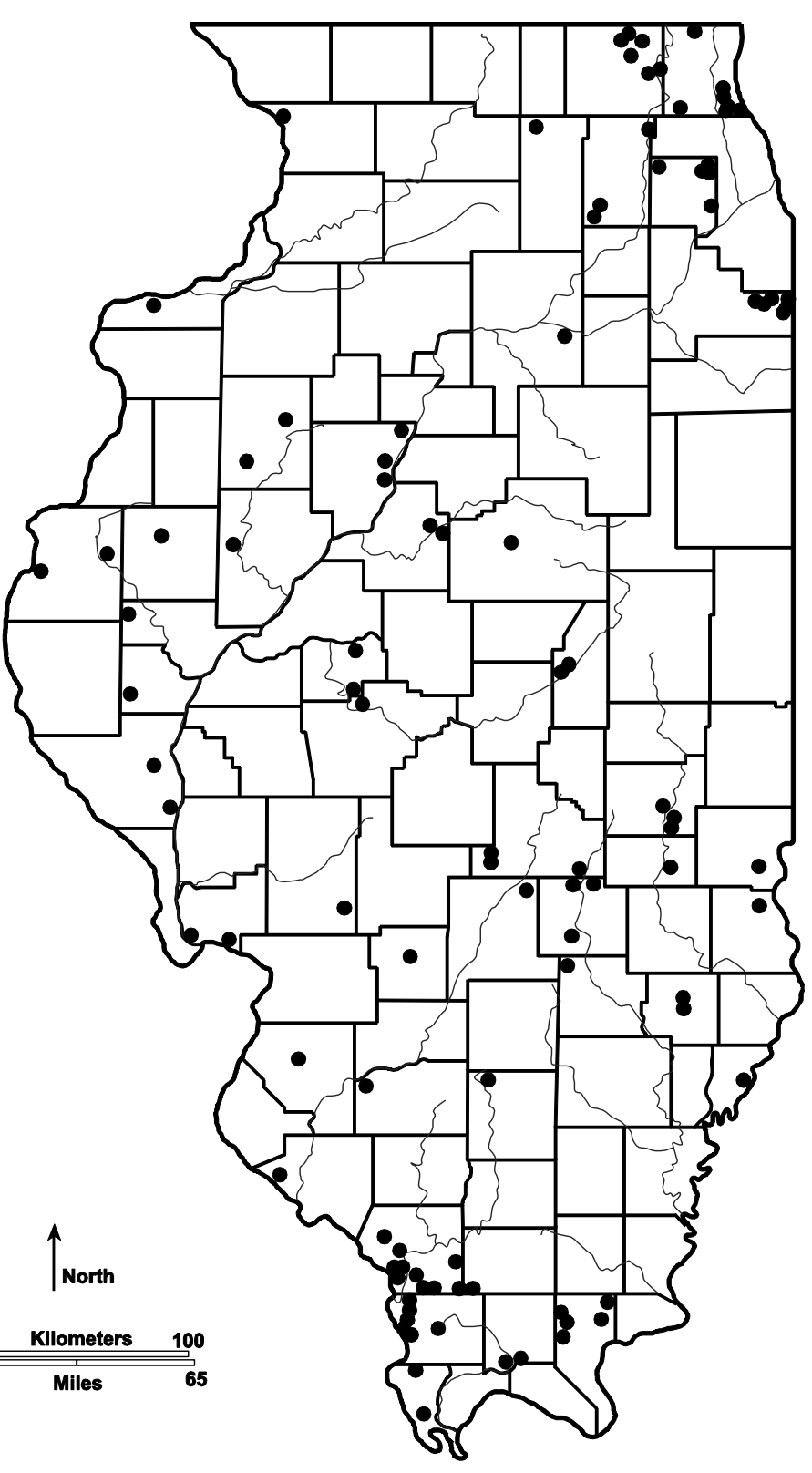

Figure 4. Known locality records for the red-bellied snake Storeria occipitomaculata in Illinois (except Cook County). See Fig. 5 for Cook County. Cartography by J. Thomas.

Illinois outside of Cook

County are shown in Fig. 4; records for Cook County are in Fig. 5. A number of the plotted symbols on the two maps represent two or more nearby collection sites. Specimens were collected (or in some cases captured, identified,

and released) by scientists and naturalists over the past 150+ years (ca. 1854-2010). Thus, Figs. 4 and 5 should not be construed to represent the present distribution of $S$. occipitomaculata in Illinois because some 


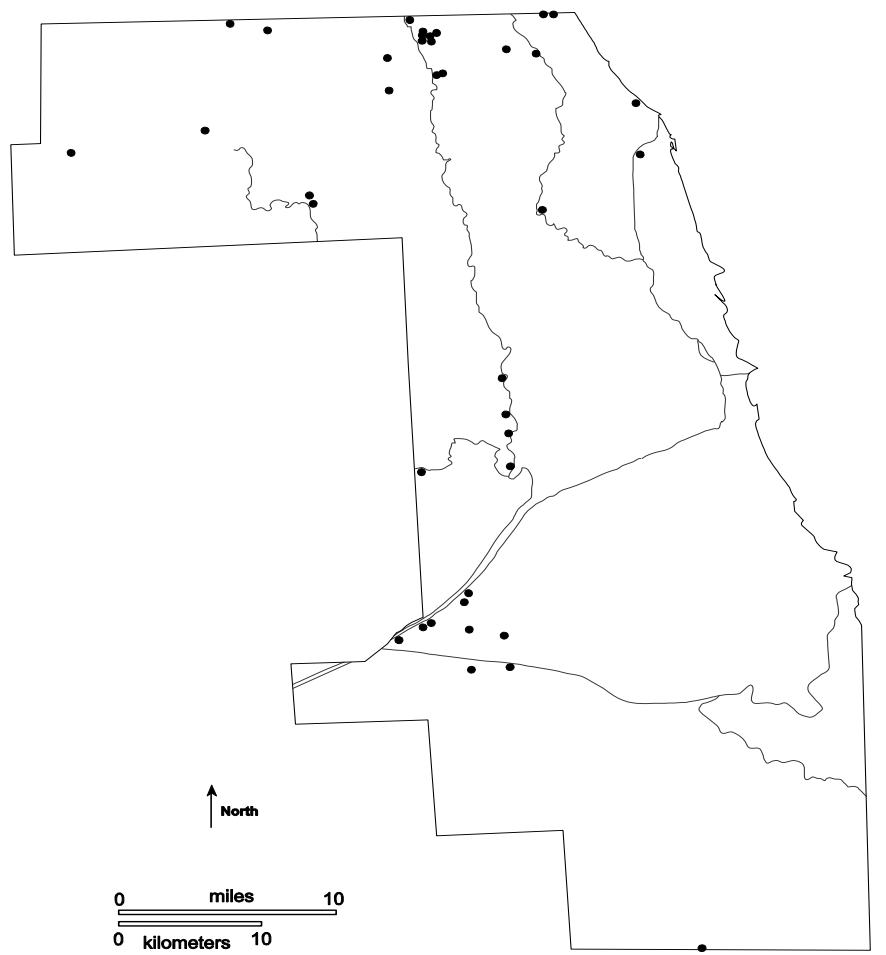

Figure 5. Known locality records for the red-bellied snake, Storeria occipitomaculata in Cook County, Illinois. Cartography by J. Thomas.

populations undoubtedly became extirpated over the past $150+$ years due to habitat changes, and it is likely that there are undiscovered populations in the state.

Two specimens we examined (SIUC 4095, INHS 6121) lacked heads and immediate postcranial regions, and we could not identify them. However, they were collected by competent herpetologists who would have identified them by their red venters. Also, there are other records for the species close to the locations of these two specimens.

Three specimens we examined (FMNH 98593, 98594; ISM 688486) were skeletons. Holman (2000) indicated the difficulty of separating the vertebrae of $S$. occipitomaculata from those of other species. Thus, we did not attempt to identify the skeletons. However, there are other records for the snake at the locality of FMNH 98593 and 98594. The label of ISM 688486 which we examined indicates that $\mathrm{S}$. Ahler (an archaeologist) collected it at Modoc
Rock Shelter (National Historic Landmark and archaeological dig) in Randolph County. No alcoholic specimens or literature records are available for this county, and ISM 688486 is thus a county record. Meredith Mahoney (pers. comm.), Illinois State Museum, informed us that the handwriting of Rick Purdue (her predecessor as curator of vertebrates) is on the specimen label, and that he likely identified the specimen and prepared the skeleton. Purdue and Webb (1986) listed two S. occipitomaculata in an inventory of skeletons in the Illinois State Museum. As Purdue is a competent herpetologist, we accept this record. Three publications presented erroneous locality records: Cagle (1942) in Jackson County (misinterpretation of locality record for museum specimen); Smith (1961) in Monroe County (lack of museum specimen, literature record, or field notes); Ernst (2002) in Kankakee or Iroquois counties (mapping error). Some other specimens had locality data that were vague or incomplete. Thurow (1999) wrote that he "found a few individuals south, west, and southwest of Macomb" in McDonough County. Also, Thurow and Sliwinski (1991) reported records from Adams, Hancock, Kane, Knox, McDonough, and Pike counties with no details. Specimens for these records were not available for examination and thus we could not plot them.

We found evidence of $S$. occipitomaculata from 46 counties in Illinois. Previous major distributional studies of S. occipitomaculata in Illinois (Trapido 1944; Smith 1961; Phillips et al. 1999) obtained records from 7, 20, and 32 counties, respectively. Ernst's (2002) locality records for Illinois were plotted on a map lacking county boundaries, thus we could not 
determine the number of county records. Thus, the known range has increased substantially compared to previous studies. Storeria occipitomaculata has been collected from Alexander County, the most southern county in the state, and Lake and McHenry counties on the northern boundary of the state. There are also records in the far western part of Illinois (Hancock County) and in counties along the eastern border (Clark, Crawford, Will). There are three regions where the species has not been found: (1) along the eastern border of the state from Kankakee and Grundy counties in the north through Edgar and Douglas counties in the south, (2) the north to north-central portion of the state from Stephenson and Winnebago counties along the northern state line through Stark and Henry counties further south, and (3) a roughly circular area in southeastern Illinois. Perhaps the habitat is unsuitable in these areas, but there do not seem to be any readily identifiable natural features that characterize these areas that would indicate unsuitability for S. occipitomaculata. These areas have not been surveyed extensively by herpetologists and this may explain the lack of records.

It seems likely that many of the localities represent relictual populations (particularly in central and northern Illinois). The species simply cannot inhabit areas of intense habitat modification. However, the distribution of the species may be relatively continuous in a few regions (e.g., forest preserves along the DesPlaines River in northern Cook County and southern Lake County).

\section{Habitat}

The best early description of habitats of $S . o$. occipitomaculata throughout its range in the USA and Canada was given by Wright and Wright (1957): wooded regions (many types), more on upland hilly ridges than lowlands, near rivers, damp meadows, lake shores, moist ground, sphagnum mats, swamp edges, bog edges, marshes, sandy ridges, hilly regions, hillsides, dry flat areas, stone covered ground, limestone hill, open fields and pastures, semi-open areas, rarely in plowed fields, along edges of wet places, open areas such as roads and roadsides, fence rows, fire lanes, swimming 3.0-4.6 $\mathrm{m}$ from shore, climbing in shrubs, gravel pit, and stone quarry. They concluded "All in all, it is widespread in distribution and habitat but most likely to be found in high, hilly, stony, wooded areas." Many other publications in the nineteenth, twentieth, and early twenty-first centuries gave abbreviated descriptions of the habitat type of S. occipitomaculata, but there has been no detailed study of the habitat of the species throughout its range.

Brief, indirect comments on the habitat of $S$. occipitomaculata were made by Davis and Rice (1883) in the first list of Batrachia and Reptilia in Illinois ("Common in all parts of the State."), and Garman (1892) in the first extensive survey of the herpetofauna of Illinois ("Occurs everywhere within our limits."). Parmalee (1955) wrote that the species was "restricted to moist areas, quite often in wooded sections" in a popular publication on Illinois reptiles. In the first comprehensive study of the herpetofauna in Illinois, Smith (1961) indicated that $S$. occipitomaculata usually inhabits wooded areas but sometimes occurs in wet meadows, prairies, and pastures. In their Illinois field guide, Phillips et al. (1999) wrote that habitat was "Forests and moist woods, occasionally in pastures, bogs, and wet meadows, even in predominantly prairie counties." There has been no comprehensive survey of habitat types in Illinois.

Following, is information (71 records) on habitat types occupied by $S$. occipitomaculata in Illinois based on museum records, field notes, and literature records. A number of these records represent more than one locality.

\section{Alexander County - pristine Austroriparian forest on Mississippi River floodplain, Horseshoe Lake Island, L. Brown field notes; woods, Horseshoe Lake Island, R. Brandon field notes [probably not the same locality as listed previously, as the island is rather large].}

Brown County - dry streambed, $5 \mathrm{mi}$ [8.0 km] S Timewell 39.93399 -90.87452, ISM museum record. 
Carroll County - railroad ballast, along riparian woodlands and marsh in Mississippi River Bottoms, opposite rocky/wooded bluffs, along railroad tracks across from main entrance to Mississippi Palisades State Park 15T 733221E 4670072N, M. Redmer field notes.

Clark County - upland mixed deciduous forest surrounded by agriculture, $120 \mathrm{~m} \mathrm{E}$ 1400th Street (County Road 1400E), S of Joe's Fork Mill Creek, Melrose Township 39.25662 -87.74271 , INHS museum record.

Coles County - "shrub/young forest" [probably old field], Fox Ridge State Park, north annex, Foster and Hampton (2003); mesic hardwood forest on ridge top, reasonably mature forest with little understory, $75 \mathrm{~m} \mathrm{~N}$ and W of Embarras River, Fox Ridge State Park N annex, Hutton Township, S. Mullin field notes; $\mathrm{N}$ facing slope of mature forest that drains into Ridge Lake (human made) ca. $40 \mathrm{~m}$ downslope, sparse understory, Fox Ridge State Park main portion, Hutton Township, S. Mullin field notes; old field along foundation of old barn, ca. $40 \mathrm{~m}$ from forest edge, Warbler Woods Nature Preserve, Hutton Township, S. Mullin field notes; "upland woods," near Charleston, Hankinson (1917).

Cook County - "restriction of this species in the Chicago Region to the morainal ridge," NW of Chicago, Schmidt and Necker (1935); "forested morainal region," Smith (1961); "forested moraines," Chicago region, Phillips et al. (1999); "Although essentially a woodland species, this snake unhesitatingly invades various situations adjacent to woods. Among these are pastures, fallow fields, abandoned farms, and roadside ditches... a distinct love of moisture...bogs and wet meadows...limited to the forested morainal ridge (and vicinity)," immediately W and NW of Chicago, Pope (1964); roadside, cool season grasses along edge of wet woodland (northern flatwoods), Potawatomi Woods Forest Preserve, Portwine Tract along Dundee Road frontage road just W of Interstate 294, 16T 426402E 4665592N, M. Redmer field notes; successional meadow/ prairie remnant with numerous prairie plants surrounded by woodland, Potawatomi Woods Forest Preserve, Portwine Tract S of Forestview Lane 16T 426776E 4666241N, M. Redmer field notes; small old field opening in forest which has old foundations and an abandoned parking lot, Potawatomi Woods, M. Ignoffo field notes; series of small ( $<0.25$ ha) open meadows in woodland, Dam 1 Woods Forest Preserve along old north-south bridal path E of DesPlaines River 16T 425822E 4665359N, M. Redmer field notes; 40 ha grass meadow and prairie, Dam 1 Woods Forest Preserve, WillowSanders Tract NW of intersection of Willow and Sanders roads 16T 427205E 4662722N, M. Redmer field notes, INHS museum record, C. Phillips field notes (Fig. 6); "edges of forest tracts...savanna, old fields, meadows, and open woodland...relatively undisturbed preserves in built-up areas," scrub, not deep forest, clearings in forest, sometimes an edge species, summary of extensive field work in Busse Woods South, Dam No. 1 Woods, Deer Grove East, Paul Douglas Preserve, Potawatomi Woods, Red Gate Woods, Shoe Factory Woods, and Skokie Lagoons (divisions or preserves of Forest Preserve District of Cook County), T. Anton (undated; 1999; pers. comm.); oak forest, Park Forest at Will County line, FMNH museum record; equestrian path near river, E of Prospect Heights, Cook County Forest Preserve, in vicinity of Willow and Sanders roads, INHS museum record; in mowed right of way, N side of Dundee Road about 300-400 ft [91.4-121.9 m] E of Port Wine Road T42N R11E, INHS museum record; prairie remnant with wet prairie, marsh, sedge meadow, and some oak savanna, near railroad tracks along $\mathrm{N}$ branch of Chicago River, Somme Prairie, M. Ignoffo field notes; throughout forest with many poorly drained depressions, highest density in openings in the forest, Busse Woods, M. Ignoffo field notes. [A few Cook County records may be duplicates.]

Crawford County - "upland mesic oak forest," Crawford County Conservation Area 39.0987 ${ }^{\circ} \mathrm{N}, 87.6983^{\circ} \mathrm{W}$, Petzing et al. (2009). 


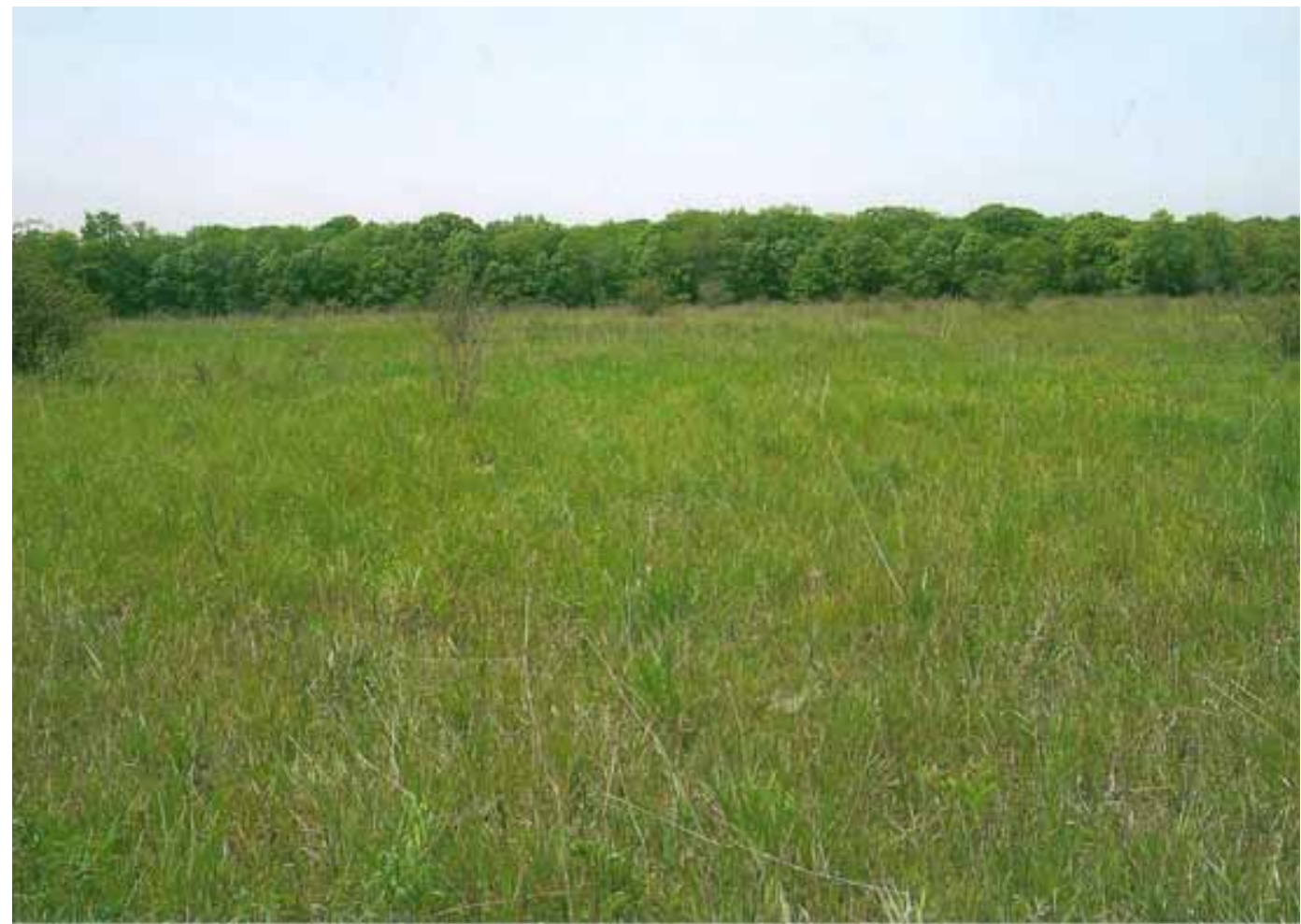

Figure 6. Prairie habitat (spring) in northeastern Illinois (SW of intersection of Sanders and Forest View roads, Cook County). This region supports a substantial population of red-bellied snakes, Storeria occipitomaculata. Photo by M. Dreslik.

DeKalb County - " grassy area, ca. 10-15 m from the edge of Owens Creek within the old Boy Scout Camp," near Kirkland, Franklin Township 8852'30” N, 4207'30” W, R3E T43N, Andre and Walley (2002).

DuPage County - successional meadow/ prairie remnant in oak flatwoods area, Wood Dale Grove Forest Preserve N of Third Avenue 16T 419536E 4644200N, M. Redmer field notes; successional meadow along wooded wetland in oak flatwoods area, Wood Dale Grove Forest Preserve S of Third Avenue 16T 419177E 4643959N, M. Redmer field notes; clearing along west pond/wetland area in oak flatwoods, Fischer's Woods Forest Preserve 16T 420213E 4642979N, M. Redmer field notes; "old field east of the wetland...[and] northwest of the borrow pit," ca. $600 \mathrm{~m} \mathrm{~S}$ of Third Avenue between Wood Dale Road and Central Avenue T40N R11E Sec. 22, Cochran (1989) [may be the same or near one of M.
Redmer's populations above]; in oak forest near edge, Wood Dale, FMNH museum record; well drained soil along railroad near permanent pond, mainly prairie and prairie-like habitats with stands of cottonwoods and many invasive shrubs near railroad and ponds, Pratt's Wayne Woods (Fig. 7), M. Ignoffo field notes; small scrubby old field bordered by open woodlands, usually edge of red oak/shagbark hickory savanna, not more forested parts of preserve, Woodale Grove, M. Ignoffo field notes.

Effingham County - on pond berm in old field, Wildcat Hollow State Habitat Area $38^{\circ}$ 59.56', - $88^{\circ} 36.40^{\prime}$, INHS museum record.

Fayette County - gravel road by pond, 0.3 $\mathrm{km} \mathrm{S}$ of Lorton Bridge (Kaskaskia River), 39.17562 -88.89418, INHS museum record.

Jackson County — woods, Little Grand Canyon, R. Brandon field notes; gravel road 


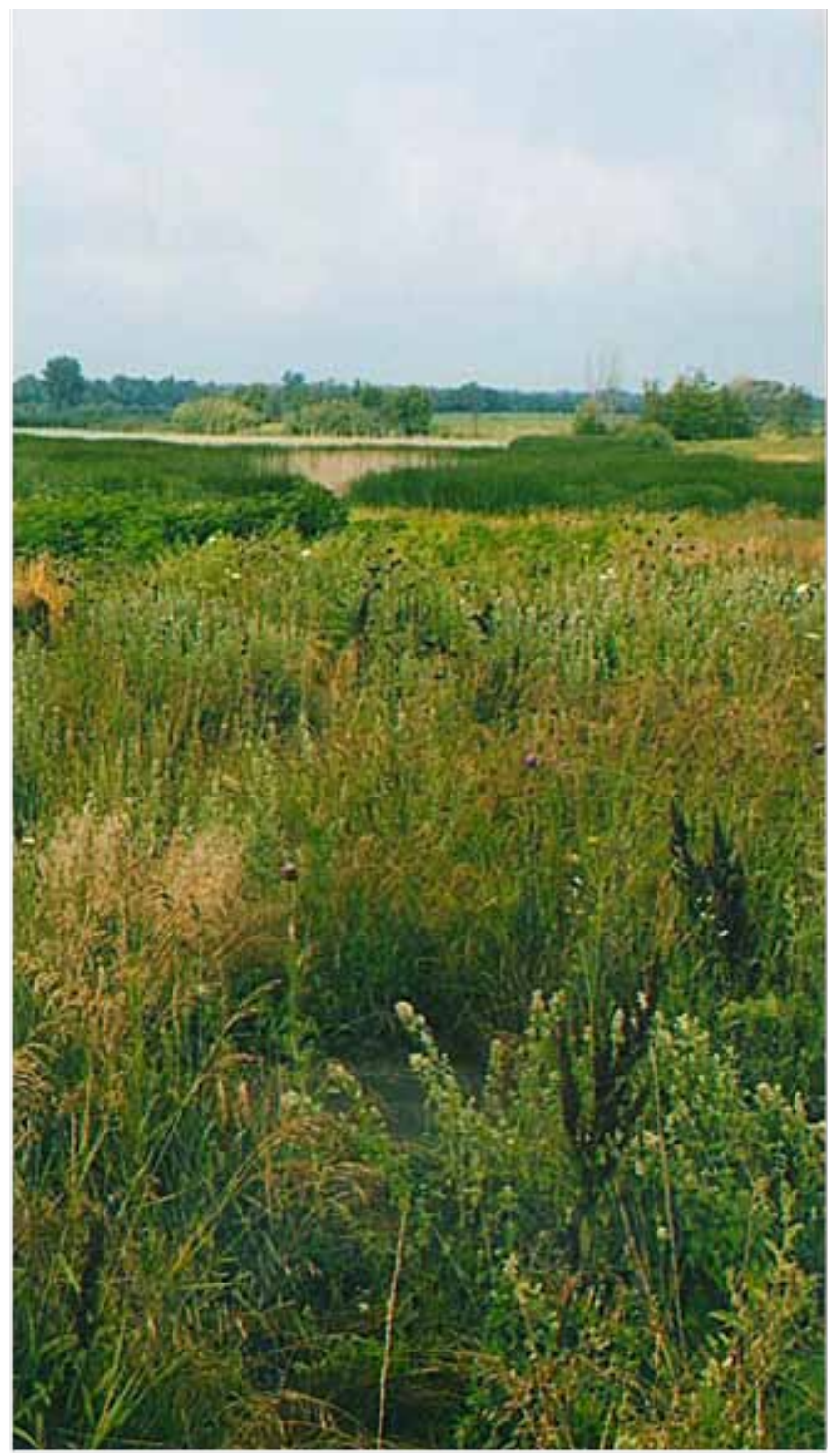

Figure 7. Prairielike habitat (summer) occupied by red-bellied snakes, Storeria occipitomaculata in northeastern Illinois (Pratt's Wayne Woods, DuPage County). Photo by M. Ignoffo. area of hillside above floodplain, Shawnee National Forest near Kinkaid Creek W of Route 151 and SW of Ava 16S 275264E 4192563N, M. Redmer field notes.

Jersey County - bluff top in woods, Pere Marquette State Park, R. Brandon field notes.

Kane County-edge of open field near forest, Big Rock Forest Preserve, on Jericho Road ca. 2-4 mi [3.2-6.4 km] W of Route 47, T. Anton (pers. comm.).

Lake County - "forested morainal region," [no specific locality], Smith (1961); "forested areas," ("sugar maple/ basswood...oak/hickory... Old Field" [sic] in table 1), "in the southern half of the valley" of DesPlaines River, Lake County Forest Preserve District, Bushey (1979); successional meadow/ prairie in oak flatwoods area, Ryerson Woods Conservation Area, open meadow along Riverwoods Road 16T 425378E 4669929N, M. Redmer field notes; drier grassy areas near marshes and at edge of savanna, farmed until mid 1900s, Cuba Marsh, M. Ignoffo field notes.

LaSalle County - "edge of degraded dry-mesic upland forest near small intermittent stream," Marseilles State Fish and Wildlife Area NE $\square$ SE $\square$

through woods, Hickory Ridge Road, S. of Murphysboro, R. Brandon field notes; woods ca. $10 \mathrm{~m}$ from Happy Hollow Road on E side of Fountain Bluff on Mississippi River floodplain SW $\square$ NE $\square$ Sec 1 T10S R4W Grand Tower Township, L. Brown field notes; "on a wooded ridge," near Fountain Bluff, Minton and Minton (1948); clearing in woodland in flat
Sec. 30 T33N R5E, Bittner and Bittner (2001).

Macoupin County - wooded area near city reservoir (Mount Olive Lake), $3 \mathrm{mi}$ [4.8 km] NW Mount Olive, Sec. 28 T8N R6W, ISM museum record; select cut oak hickory forest, behind shed, grey forest soils, $3.4 \mathrm{~km} \mathrm{ENE}$ 
of Benld and N of New Mount Olive Lake at Bryant Sawmill, Gillespie South Quadrangle, $39^{\circ} 6$ ' 23"N 8945' 35"'W, SE $\square$ Sec. 28 T8N R6W, Bryant (1999) and INHS museum record.

McDonough County - "usually on wooded slopes," S, W, and SW of Macomb, Thurow (1999).

McHenry County-low hill just E of Streets Lake, (Goose Lake Conservation District), $3 \mathrm{mi}$ [4.8 km] W Richmond on Route 173, 42.47546 -88.38688, INHS museum record; oak savannah, Glacial Park 16T 390449E 4696757N? [sic], M. Redmer field notes; savannahs (on gravelly glacial kames) on well drained slopes, Glacial Park, M. Ignoffo field notes [possibly the same locality as M. Redmer's population listed previously]; oak savannah, SE of Hebron at McCollom Lake Hunt Club 16T 384365E 4700835N, M.

Redmer field notes.

Piatt County - prairie reconstruction...by Allerton prairie, Robert Allerton Park 39.99566 -88.636 , INHS museum record.

Pike County - grassy area near edge of hay field ca. $7 \mathrm{~m}$ from woods, $4.6 \mathrm{~km}$ E of Pittsfield and $2.1 \mathrm{~km} \mathrm{~N}$ of Route 106, NE $\square$ SW $\square$ Sec. 11 T5S R3W Newburg Township, A. Nash (pers. comm.).

Pope County - woods on path, Bell Smith Springs, SIUC museum record; dry creek bed in forest with ephemeral streams, One Horse Gap Lake, M. Ignoffo field notes.

Shelby County - mixed hardwood forest that was likely logged in the last 60 years, thick understory layer including invasive species like Lonicera (honeysuckle), bordered by a pine plantation to the $\mathrm{N}$ (about $75 \mathrm{~m}$ to nearest edge) and otherwise surrounded by row crop agriculture (about $225 \mathrm{~m}$ to nearest edge), Rhodes-France Scout Camp, Oconee Township, S. Mullin field notes.
Tazewell County - open grassy area of front yard of rural residence ca. $10 \mathrm{~m}$ from pristine wooded valley, off Woodfield Drive $0.40 \mathrm{~km}$ E of Route 6, NW $\square$ SW $\square$ Sec. 5 T24N R2W Mackinaw Township, L. Brown field notes; open grassy area of backyard of rural residence near mulch pile near woods, off King Road 2.1 $\mathrm{km} \mathrm{N}$ of Route 9, SE $\square$ SW $\square$ Sec. 12 T24N R2W Mackinaw Township, L. Brown field notes.

Union County - gravel road through woods, Pine Hills [Swamp], road below bluff, R. Brandon field notes; climbing on plant ca. $40 \mathrm{~cm}$ above ground in grassy area on Big Muddy River floodplain at $\mathrm{N}$ base of levee N of Winters Pond SW $\square$ SE $\square$ Sec. 4 T11S R3W, L. Brown field notes; swamp road just $\mathrm{S}$ of bluff spring, Pine Hills [Swamp] 37.5041 -89.4201 , SIUC museum record.

Washington County - "near a residential opening in an oak-hickory flatwoods," $8.6 \mathrm{~km}$ W Okawville and S Clear Lake SW $\square$ Sec. 22 T01S R05W, UTM Zone 16: N4256617m E269071m, 38²5'41 'N, 89³8'44'”W, Wilson (1999), INHS museum record.

Will County - old field and pockets of degraded prairie overgrown with successional growth of hawthorn and early successional tree species, mostly on slopes and upland areas of scrub and thickets usually not far from prairie or old field openings, Will County Forest Preserve, Plum Valley Area \#1, 0.3 km S Steger Road and $0.2 \mathrm{~km} \mathrm{E}$ of Sec. 6 centerline, D. Mauger field notes, INHS museum record; meadow and yard surrounded by woodland, banquet facility at Plum Creek Forest Preserve $1.3 \mathrm{~km} \mathrm{SW}$ of intersection of Stoney Island Ave. and Exchange Str. 16T 452344E 4586079, M. Redmer field notes; old field or Eurasian grass field close to successional scrub and just $\mathrm{W}$ of a small prairie remnant that is heavily overgrown with hawthorn scrub, close to relict forest, $3.5 \mathrm{~km}$ NE Monee at Governors State University $400 \mathrm{ft}$ [121.9 m] S of science parking lots, D. Mauger field notes, INHS 
museum record; old field with successional tree growth along fence lines, remnants of oak hickory forest occur in a low density residential area less than $0.1 \mathrm{mi}[0.16 \mathrm{~km}]$ to the $\mathrm{N}$, close to SE edge of timber line of Thorn Creek Woods Forest Preserve, E shoulder of Kings Road $0.07 \mathrm{mi}[0.11 \mathrm{~km}] \mathrm{N}$ of Exchange Ave., D. Mauger field notes; dry-mesic upland forest on trail near salamander ponds, E side of Thorn Creek Woods and W side of Western Ave., D. Mauger field notes.

Storeria occipitomaculata was also found in Indiana Dunes National Lakeshore (Hoosier Prairie Unit), Lake County, Indiana adjacent to Cook County, Illinois (A. Resetar pers. comm.). There were five localities in prairie, two in savannah, and one in an old field/disturbed area.

It is clear from the 71 habitat records in Illinois that $S$. occipitomaculata occupies a variety of environments and is not restricted to forests. Given these habitat descriptions, the most unexpected aspect is the relatively large number of references to prairie or prairielike (e.g., non-native grasslands) habitats, as well as degraded and successional stages derived from such habitats. Some prairielike areas may have originally been forest that was cleared for agriculture and then abandoned. Such extensive use of grassland habitats has not been reported with details elsewhere in the range of the species. Prairie or grassland habitats have been noted by the following other researchers, but usually as a minor component of the habitat occupied by the species: Alabama-open fields (Linzey 1979); Connecticut_old pasture, open disturbed areas, grassy powerline rightof-way (Klemens 1993); Florida-wet prairie hammocks (Tennant et al. 1997); Georgiaopen, parklike pasture in bottomland (Neill 1951); Iowa-only in prairies in NW Iowa (M. Lannoo pers. comm.); Kentucky - open field, pasture (Barbour 1950), fields (Barbour 1952), meadows, pastures (Barbour 1971); Mainesmall grassy clearing (Fowler and Sutcliffe 1952), open fields, marsh edges (Hunter et al. 1992, 1999); Michigan - a clearing (Langlois 1924), "in clearings and partially wooded places" (Blanchard 1937), marshy country (Minton 1944), open areas, old pasture (Heatwole and Getz 1960), meadows (Holman et al. 1993), meadows, open fields, other open clearings in Pictured Rocks National Lakeshore (T. Anton pers. comm.); Minnesota-prairie (Ernst 1974), grassy areas (C. Ernst pers. comm.), moist grassy meadows (Oldfield and Moriarty 1994); Mississippi-coastal pine meadows (Cook 1954); New York-open pastures, fields (Bishop 1927), upland meadows (Gibbs et al. 2007); North Carolina-meadows, old fields, open places (Palmer and Braswell 1995); Ohio - wet meadows (Conant 1938, 1951), successional old field (Meshaka et al. 2009); Pennsylvania - small grassy hilltop (Lachner 1942), fields, pastures (Conant 1942), overgrown field, clearing (McKinstry and Felege 1974), old field (Gray 2002), mixed rangeland, rolling fallow fields (Meshaka et al. 2009); South Dakota - grassy places (Over 1923, 1943); Texas - old fields, open places (Werler and Dixon 2000); Virginia-old fields (Mitchell 1994); West Virginia_wet sedgy meadows (Green and Pauley 1987); Wisconsin - marshy country (Minton 1944), open upland habitats (mostly grassland), shallow open marshes (Kapfer 2010), restored prairie in sand area, Chetek, Barron County (F. DeSerto pers. comm.), open areas, old fields, grassy roads through deciduous forest, Ashland County (D. Moll pers. comm.); Great Lakes Region-pasture, fields, marshes (Harding 1997); New England-damp meadows, upland meadows, marshy areas (DeGraaf and Rudis 1983); Eastern United States - prairies (Conant and Bridges 1939); Nova Scotia, Canadagrassy and grassy heath habitats, margins of old fields (Gilhen 1984); Maritime Provinces of Canada-open country (Cox 1903); Canadaclearings, fields (Froom 1972); eastern and central North America-damp meadow, open fields, open pastures, open areas, semi-open areas, marshy country, exposed fire lanes (Wright and Wright 1957), open fields, borders of marshes (Ernst and Barbour 1989, Ernst and Ernst 2003), edges of forest clearings (Tennant et al. 2003).

Two references from Canada suggested a more widespread use of prairielike habitat 
by S. occipitomaculata. Gregory (1977), working in the Interlake Region of Manitoba (between Lake Winnipeg and Lake Manitoba) stated "Most specimens were found in generally open areas such as marshes or meadows, although a few were found in areas of aspen forest." In a book on reptiles and amphibians of Canada, Cook (1984) indicated "Clearings, pastures, old fields, abandoned farms, and bush appear to be their typical habitat" (for both $S$. occipitomaculata and S. dekayi).

Thus, reports of prairie, prairielike habitats, and their degraded and successional derivatives are widespread and numerous in eastern North America. However, Illinois seems unusual in that a relatively large number of these habitats are occupied by S. occipitomaculata, whereas in most other areas they apparently make up a minor component of the species' habitat.

A major environment type that has not been noted to be occupied by $S$. occipitomaculata in Illinois is cultivated fields. We have carried out numerous herpetological surveys and ecological studies throughout Illinois for various state agencies (e.g., Illinois Department of Transportation). These surveys often involved searching cultivated fields or traversing through them. Such searches necessitated keeping our eyes focused on the substrate at all times, but we never encountered S. occipitomaculata in any cultivated field.

\section{Zoogeography}

After reviewing the botanical evidence, Transeau (1935) delineated the Prairie Peninsula in the Midwest. This ecosystem was a Holocene extension eastward from the Great Plains across Missouri, Iowa, and Illinois, as well as into Indiana and portions of adjacent states. Subsequently, Schmidt (1938) suggested that the Prairie Peninsula served as a "highway" for a number of grassland adapted species of reptiles and amphibians from the Great Plains in the post-Wisconsin extension

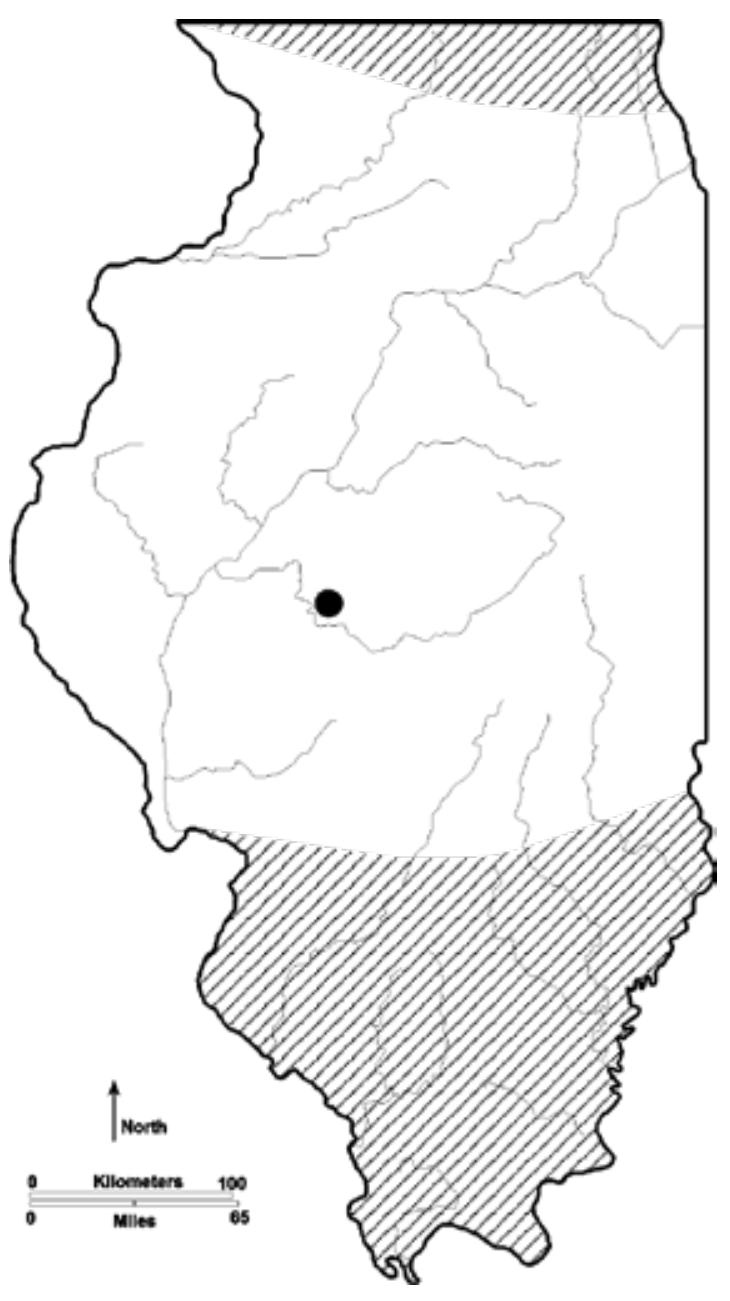

Figure 8. Distribution of the red-bellied snake, Storeria occipitomaculata in Illinois based on pre-1944 locality records for which museum specimens were available from seven counties (after part of Map 2, Trapido, 1944, American Midland Naturalist vol. 31). The darkened spot (Athens, Menard County, MCZ 5583) was presumed to represent an isolated record "outside the general range of the species" (Trapido, 1944). Permission to use granted by W. Evans, Editor, American Midland Naturalist. Cartography by J. Thomas.

of their geographic ranges eastward. This was followed by Schmidt and Davis (1941) who gave the habitat of S. occipitomaculata as "woodland."

Trapido (1944) published the first and only extensive monograph on the genus Storeria which included distribution maps for each species. His map for S. occipitomaculata (Fig. 8) showed a broad band across Illinois where it 
was thought the species did not occur because of lack of distributional records. At that time, locality records based on museum specimens were available for only seven counties, all except one in southern and northern Illinois. Trapido (1944) plotted the one record from Athens, Menard County (MCZ 5583), as isolated in the middle of the former Prairie Peninsula, and consulted Schmidt about its significance.

Schmidt pointed out (postscript in Trapido 1944) that lack of distributional records for $S$. occipitomaculata in a broad band across the central Midwest gives support for his theory that there was a post-Wisconsin extension of grassland eastward from the Great Plains. He doubted the authenticity of the Athens record, and further indicated that S. occipitomaculata failed to adapt to drier environmental conditions and lack of cover preventing its entry into the prairie. However, he noted the species was able to move into the more suitable northern forests.

We examined the Athens specimen in detail. It was collected by E. Hull and recorded in the MCZ catalogue in 1886. Although its head is damaged, the snake is clearly identifiable as $S$. occiptomaculata, and there is no reason to doubt its authenticity.

The south side of the town of Athens abuts Town Branch Creek and its associated ravines with the creek running through some of the town (Athens Quadrangle, Illinois, 7.5 Minute Series, Topographic, 1966 U.S. Geological Survey, Washington, D.C.). Considerable land along Town Branch is wooded, whereas the areas to the east, north, and west of Athens are mostly flat land (probably former prairie) and presumably tilled.

There are also more recent museum specimens available from northern Menard County (ISM 622390, $1.5 \mathrm{mi}$ [2.4 km] S of Salt Creek on Route 29), and northern Sangamon County (ISM 622095, 3 mi [4.8 km] NW Springfield), which is only ca. $7.6 \mathrm{~km}$ SSE of Athens. Furthermore, prior to the publication of Trapido (1944), Garman of the INHS reported (1892) S. occipitomaculata from Peoria and Normal, Illinois, in the heart of the former Prairie Peninsula. However, we have been unable to find museum specimens for these records.

The species was also reported to inhabit prairies or prairielike habitats before publication of Trapido (1944). The most important reference was Conant and Bridges (1939), which indicated the species inhabits prairies. Others include Cox (1903), Over (1923, 1943), Langlois (1924), Bishop (1927), Blanchard (1937), and Conant (1938, 1942). Even Trapido (1944) indicated that $S$. occipitomaculata inhabited "open fields." In contrasting $S$. dekayi with $S$. occipitomaculata, he wrote that the latter "is a snake of more open places."

Schmidt (in Trapido 1944) based his zoogeographic interpretations on the best available evidence of the time (museum records). We presume he must have thought Trapido (1944) was dealing with the complete, or nearly complete, distribution of $S$.

occipitomaculata in Illinois. He could not have predicted the plethora of distributional records yet to be discovered.

After Trapido (1944), several other papers were published that are pertinent to the zoogeography of $S$. occipitomaculata in Illinois. An eastern movement for the plains gartersnake Thamnophis radix from the Great Plains into the Prairie Peninsula after the Pleistocene was postulated by Conant et al. (1945). They suggested colonization occurred during the Xerothermic (Hypsithermal), a dry, warm phase in the mid Holocene. This was in contrast with Schmidt (1938), who suggested that colonization occurred immediately south of the melting Wisconsin Episode glacial stage in a tundra belt that was succeeded by prairie. Smith (1957) presented more distributional evidence for Schmidt's (1938) Prairie Peninsula zoogeographic theory, but did not mention S. occipitomaculata. Like Conant et al. (1945), the Hypsithermal was favored by Smith (1957) as the period of eastern colonization. In a paper on the distribution of the herpetofauna in Illinois and Indiana, Smith and Minton (1957) suggested: "the reduced forest in Illinois would seem to 
provide the least amount of suitable habitat for the species [S. occipitomaculata]" and "They [S. occipitomaculata, D. punctatus] may represent elements of an earlier forest fauna partly obliterated in our area by a subsequent eastward extension of grassland." Holman (1992a) suggested that $S$. occiptomaculata was one of several species of snakes that were primary invaders of postglacial southern Michigan about 12,500 YBP with the beginning of colonization by spruce forests. We found no other references relevant to the zoogeography of S. occipitomaculata in Illinois.

The stratigraphy of the Pleistocene in Illinois, including evidence of glaciation, was monographed by Willman and Frye (1970). The Lake Michigan Lobe of the Wisconsin Episode (similar to the Wisconsinan Age of Willman and Frye 1970) was revised and reclassified by Hansel and Johnson (1996). The last glaciation (Laurentide Ice Sheet) in Illinois occurred during the Michigan Subepisode from ca. 26,000-22,000 YBP until ca. 12,000 YBP. The maximum glaciation occurred during the Shelby Phase about 22,000-20,000 YBP. This glaciation occupied northeastern and east-central Illinois, extending as far south as northern Cumberland County and as far west as eastern Peoria and Stark counties and western Bureau County. Deglaciation in Illinois began after the maximum of the Shelby Phase (ca. 20,000 YBP) and was complete by the end of the Crown Point Phase (ca. 14,000 YBP) in the Late Michigan Subepisode (Hansel and Johnson 1996). Glacial retreat resulted in tremendous quantities of meltwater which formed large glacial lakes.

The Michigan Subepisode was followed by the Hudson Episode (ca. 12,000 YBP to present), which in Illinois (Hansel and Johnson, 1996) was composed of the Greatlakean Substage (ca. 12,000 to 7,000 YBP) and the Holocene (ca. 7,000 YBP to present), which were characterized by complete deglaciation and a great reduction in ponded meltwater.

Landform evidence from the Pleistocene indicates that permafrost and tundra existed near the ice rim, but fossils of tundra-adapted animals and plants indicate the tundra was discontinuous and frequently a mosaic with boreal forest (Pielou 1991). Furthermore, this band of tundra was narrow (Deevey 1949; Wright 1987; Dawson 1992). Beyond the tundra zone was a belt of boreal forest, but this was also narrow (Wright 1987) and probably a mosaic with grassland (Rhodes 1984; Wright 1987). In some areas there was no gap between boreal forest and ice front (Pielou 1991).

The Pleistocene climatic equability hypothesis has been described by Graham and Mead (1987): "During glacial stages, species were physically forced southward by glacial ice in North America. However, resident species south of the ice sheet were not displaced en masse, because winter extremes were not accentuated. Boreal and arctic taxa were integrated with preexisting temperate communities under the more equable climate conditions." The most convincing evidence for the Pleistocene climatic equability model comes from the fossil mammalian fauna of the Pleistocene, although fossils of other terrestrial vertebrates and invertebrates as well as vegetation provide further substantiation (Graham 1985; Holman 1995).

Holman (1992b, 1995, 2000) summarized evidence of fossil herpetofauna near the margin of the ice sheet in the Michigan Subepisode. Those species are still extant and presently distributed in the temperate central Midwest. Of particular importance is the presence of fossils of three species of turtles (13,000-12,000 YPB) which are still extant: the spiny softshell, Apalone spinifera, the snapping turtle, Chelydra serpentina, and the painted turtle, Chrysemys picta. A warm July temperature (mean $>18^{\circ} \mathrm{C}$ ) is necessary for successful incubation of eggs of the European pond terrapin, Emys orbicularis, presently extinct in England but extant on the European continent (Stuart 1979). Similar warm temperatures are presumably necessary for the development of eggs of the three North American turtles (Holman 1992b, 1995). Pielou (1991) indicated that compared to modern northern tundra, the summers may have been considerably warmer in the narrow tundra zone below the Pleistocene ice margin because of the lower latitude. 
Storeria occipitomaculata is one of the most cold tolerant snake species in eastern North America. Only the common gartersnake, Thamnoophis sirtalis, is distributed further north (compare maps of Conant and Collins 1998 and Ernst 2002).

Thus, S. occipitomaculata should have been able to tolerate the climatic conditions not far from the ice rim. It is not possible at present to determine the exact time of reinvasion of deglaciated land in Illinois by S. occipitomaculata. However, we propose that this began soon after the initiation of deglaciation (after the maximum of the Shelby Phase ca. 20,000 YBP) because of the species' cold tolerance, its ability to inhabit northern prairies/prairielike habitats (Froom 1972; Gregory 1977; Gilhen 1984; and others, see Habitat) and northern coniferous forests (Ruthven 1906; Loomis and Jones 1948; Gibbs et. al. 2007), as well as the relatively temperate climate along the glacial rim. Furthermore, $S$. occipitomaculata is viviparous, which is the predominant mode of reproduction among high latitude snake species because it allows thermo-regulation by gravid females to maintain optimal temperature for embryonic development of their offspring (Gregory 2009). Storeria occipitomaculata might have followed or even occupied the narrow zones of tundragrassland and boreal forest-grassland as these environments retreated northward.

The withdrawal of glaciation was not a continuous process. Hansel and Johnson (1996) indicated that after the Shelby Phase there were at least four re-advances and retreats of glaciation in Illinois (Putnam, Livingston, Woodstock, and Crown Point phases). Thus, the area just beyond the ice margin could have been a zone of repeated extinction (particularly for slow moving and fossorial animals, as well as during winter brumation) and reinvasion during the last half of the Michigan Subepisode. However, S. occipitomaculata may have been able to retreat before the readvancing glaciation.

Glacial and slackwater lakes as well as other flooding resulted from glacial meltwater (Willman and Frye 1970). The retreating glaciation also left numerous moraines (long ridges of accumulated earth and rock debris). These moraines were deposited in concentric arcs around the present southern end of Lake
Michigan. They served as temporary dams that impounded glacial meltwater, forming large lakes between moraines and between the ice front and moraines (Willman and Frye 1970; Fentem 1978). Thus, these lakes could have delayed re-invasion by or perhaps locally extirpated S. occipitomaculata.

Much of western and central Illinois was unglaciated during the Michigan Subepisode. Thus, S. occipitomaculata could have advanced eastward from that large area in addition to moving northward from southern Illinois during glacial retreat. Reinvasion could have even occurred from the north, as much of western and central Wisconsin was unglaciated. During the Illinois and Wisconsin episodes (and earlier), there was a large driftless area in western-central Wisconsin and extreme northwestern Illinois (Glacial Map of the United States East of the Rocky Mountains, 1959,1 st ed. The Geological Society of America, New York; Holliday et al. 2002). This unglaciated area might have served as a refugium for $S$. occipitomaculata during glaciations prior to and during the Wisconsin Episode. Based on mtDNA haplotype analysis, Rowe et al. (2004) suggested that the eastern chipmunk, Tamias striatus, recolonized deglaciated land in Illinois after the Wisconsin Episode glaciations from the refugium in the unglaciated region of the northern Midwest.

Prairies are thought to have occupied much of Illinois by the peak of the Hypsithermal, ca. 8,000-6,000 YBP (King 1981; Anderson 2006). Because S. occipitomaculata can inhabit prairies as well as prairielike habitats and survive seasonal and longer droughts that occur in Illinois, the Hypsithermal may have had little effect on the snake. Holman (1992b) provided evidence that indicated the modern herpetofauna was essentially reestablished in the central Great Lakes region by medial Holocene times $(6,000-4,000$ YBP). We propose that at least by $1850, S$. occipitomaculata had dispersed throughout Illinois occupying many habitats and achieving its maximum distribution and abundance in the state. We also suggest that about 1860 , a decline in the range of $S$. occipitomaculata began in much of Illinois caused by the destructive effects of agriculture (e.g., initiation of widespread plowing and drainage) on the prairies. The history and nature of the 
destructive conversion from prairie to agriculture was covered by Brown and Rose (1988), Brown and Morris (1990), and Brown et al. (2001). By 1900, we suspect that the major portion of this extirpation was complete as most of the prairies were gone by that time. The destruction continued throughout much of the twentieth century, but on a much smaller scale through clearing of woodlands and fencerows for agriculture as well as urban expansion. At least four other small snakes (the smooth greensnake, Opheodrys vernalis, the lined snake, Tropidoclonion lineatum, Kirtland's snake, Clonophis kirtlandii, and the massasauga, Sistrurus catenatus) suffered a similar fate presumably due to agriculture in Illinois. In much of central Illinois, $S$. occipitomaculata and the other four species of snakes are distributed for the most part as relictual populations in isolated or former prairie areas or isolated woodlands and woodlands along rivers not greatly disturbed by agriculture or urbanization.

We feel it is incorrect to assume that the Prairie Peninsula in Illinois could have prevented entry of herpetofaunal species that are presumed to be poorly adapted or nonadapted to prairies. Reasons include no definitive borders of prairie in northern or southern Illinois (Fig. 9). Also, prairie was distributed in Illinois as a mosaic with woodland and other vegetational complexes and was not just confined to a belt across central-northern Illinois, but was found in all but nine counties in extreme southern Illinois. Additionally, there were numerous rivers bordered by forest that intruded deep into the Prairie Peninsula in Illinois. These could have provided avenues of dispersal for numerous organisms into the Prairie Peninsula. Lastly, and probably most importantly, one would have to prove that a given species did not occur in the Prairie Peninsula, but did occur peripherally to it, before ca. 1860 when the destruction of the Prairie Peninsula began. Few specimens of herpetofaunal species have been collected in Illinois prior to that date, and little is available for distributional studies. Thus, it may not be possible to prove that the original Prairie Peninsula excluded herpetofauna thought to be nonadapted to prairies. 


\section{Literature Cited}

Anderson, R.C. 2006. Evolution and origin of the central grassland of North America: Climate, fire, and mammalian grazers. Journal of the Torrey Botanical Society 133:626647.

Andre, M., and H. Walley. 2002. Storeria occipitomaculata. Herpetological Review 33:325.

Anton, T.G. Undated. Current distribution and status of the amphibians and reptiles within the Forest Preserve District of Cook County, Illinois. Unpublished report prepared for the Forest Preserve District of Cook County.

Anton, T.G. 1999. Current distribution and status of amphibians and reptiles in Cook County, Illinois. Transactions of the Illinois State Academy of Science 92:211-232.

Applegate, R.D., and C.W. Zimbleman. 1978. Herpetofauna of the Dixon Springs Agricultural Center and vicinity, Pope County, Illinois. Bulletin of the Chicago Herpetological Society 13:72-74.

Barbour, R.W. 1950. The reptiles of Big Black Mountain, Harlan County, Kentucky. Copeia 1950:100-107.

Barbour, R.W. 1952. Animal habitats on Big Black Mountain in Kentucky. Transactions of the Kentucky Academy of Science 13:215-220.

Barbour, R.W. 1971. Amphibians \& reptiles of Kentucky. University Press of Kentucky, Lexington.
Bishop, S.C. 1927. The amphibians and reptiles of Allegany State Park. New York State Museum Handbook 3. University of the State of New York, Albany.

Bittner, R., and T. Bittner. 2001. Storeria occipitomaculata. Herptological Review 32:280.

Blanchard, F.N. 1937. Data on the natural history of the red-bellied snake, Storeria occipito-maculata [sic] (Storer), in northern Michigan. Copeia 1937:151-162.

Bothner, R.C. 1963. A hibernaculum of the short-headed garter snake, Thamnophis brachystoma Cope. Copeia 1963:572-573.

Brown, L., A. Dubois, and D. Shepard. 2008. Inefficiency and bias of search engines in retrieving references containing scientific names of fossil amphibians. Bulletin of Science, Technology and Society 28:279-288.

Brown, L., and M. Morris. 1990. Distribution, habitat, and zoogeography of the plains leopard frog (Rana blairi) in Illinois. Illinois Natural History Survey Biological Notes 136:1-6.

Brown, L., and G. Rose. 1988. Distribution, habitat, and calling season of the Illinois chorus frog (Pseudacris streckeri illinoensis) along the lower Illinois River. Illinois Natural History Survey Biological Notes 132:1-13.

Brown, L., R. Stivers, R. Treadway, and J. Thomas. 2001. Death of the sand prairie, Part I. Bulletin of the Illinois Geographical Society 43:3-29.

Bryant, C.A. 1999. Storeria occipitomaculata. Herpetological Review 30:236. 
Burbrink, F.T., and A.K. Wilson. 1994.

Storeria occipitomaculata

occipitomaculata. Herpetological

Review 25:35.

Bushey, C.L. 1979. A survey of the herpetofauna of the upper Des Plaines River Valley, Lake County, Illinois. Transactions of the Illinois State Academy of Science 72:22-28.

Cagle, F.R. 1942. Herpetological fauna of Jackson and Union counties, Illinois. American Midland Naturalist 28:164200.

Carpenter, C.C. 1953. A study of hibernacula and hibernating associations of snakes and amphibians in Michigan. Ecology 34:74-80.

Cochran, P.A. 1989. Historical changes in a suburban herpetofauna in DuPage County, Illinois. Bulletin of the Chicago Herpetological Society 24:1-7.

Conant, R. 1938. The reptiles of Ohio. American Midland Naturalist 20:1200.

Conant, R. 1942. Amphibians and reptiles from Dutch Mountain (Pennsylvania) and vicinity. American Midland Naturalist 27:154-170.

Conant, R. 1951. The reptiles of Ohio. 2nd ed. University of Notre Dame Press, Notre Dame, Indiana.

Conant, R. 1957. Reptiles and amphibians of the northeastern states. 3rd ed. Zoological Society of Philadelphia, Philadelphia.

Conant, R., and W. Bridges. 1939. What snake is that? A field guide to the snakes of the United States east of the Rocky Mountains. D. Appleton-Century, New York.
Conant, R., and J.T. Collins. 1998. A field guide to reptiles \& amphibians. Eastern and central North America. 3rd ed. expanded. Houghton Mifflin Company, Boston.

Conant, R., E.S. Thomas, and R.L. Rausch. 1945. The plains garter snake, Thamnophis radix, in Ohio. Copeia 1945:61-68.

Cook, F.A. 1954. Snakes of Mississippi. Survey Bulletin, State Game and Fish Commission, Jackson.

Cook, F.R. 1984. Introduction to Canadian amphibians and reptiles. National Museum of Natural Sciences, National Museums of Canada, Ottawa.

Cox, P. 1903. The snakes of the Maritime Provinces of Canada. Proceedings of Miramichi Natural History Association 3:11-20.

Criddle, S. 1937. Snakes from an ant hill. Copeia 1937:142.

Davis, N.S., Jr., and F.L. Rice. 1883. List of Batrachia and Reptilia of Illinois. Bulletin of the Chicago Academy of Sciences 1:25-32.

Dawson, A.G., 1992. Ice age earth, late Quaternary geology and climate. Routledge, London.

Deevey, E.S., Jr. 1949. 3. Biogeography of the Pleistocene, Part I: Europe and North America. Bulletin of the Geological Society of America 60:1315-1416.

DeGraaf, R.M., and D.D. Rudis. 1983. Amphibians and reptiles of New England, habitats and natural history. The University of Massachusetts Press, Amherst. 
Ernst, C.H. 1974. Taxonomic status of the red-bellied snake, Storeria occipitomaculata, in Minnesota. Journal of Herpetology 8:347-351.

Ernst, C.H. 2002. Storeria occipitomaculata (Storer) red-bellied snake. Catalogue of American Amphibians and Reptiles 759.1-759.8.

Ernst, C.H., and R.W. Barbour. 1989. Snakes of eastern North America. George Mason University Press, Fairfax, Virginia.

Ernst, C.H., and E.M. Ernst. 2003. Snakes of the United States and Canada. Smithsonian Books, Washington, D. C.

Fentem, A.D. 1978. The physical environment. Pages 21-107 in Nelson, R. E., ed. Illinois, land and life in the prairie state. Kendall/Hunt Publishing Co., Dubuque, Iowa.

Foster, C.D., and P. Hampton. 2003. Amphibians and reptiles in three state parks in east-central Illinois. Transactions of the Illinois State Academy of Science 96:219-228.

Foster, C.D., and S.J. Mullin. 2007. Updated and new amphibian and reptile records from Clark County, Illinois. Herpetological Review 38:238-239.

Fowler, J.A., and R. Sutcliffe. 1952. An additional record for the purple salamander, Gyrinophilus p . porphyriticus from Maine. Copeia 1952:48-49.

Froom, B. 1972. The snakes of Canada. The Canadian Publishers, McClelland and Steward, Ltd., Toronto.
Garman, H. 1892. A synopsis of the reptiles and amphibians of Illinois. Bulletin of the Illinois State Laboratory of Natural History Vol. III, Art XIII:215-388.

Gibbs, J.P., A.R. Breisch, P.K. Ducey, G. Johnson, J.L. Behler, and R.C. Bothner. 2007. The amphibians and reptiles of New York state: identification, natural history, and conservation. Oxford University Press, New York.

Gilhen, J. 1984. Amphibians and reptiles of Nova Scotia. Nova Scotia Museum, Halifax.

Graham, R.W. 1985. Diversity and community structure of the Late Pleistocene mammal fauna of North America. Acta Zoologica Fennica 170:181-192.

Graham, R.W., and J.I. Mead. 1987. Environmental fluctuations and evolution of mammalian faunas during the last deglaciation in North America. Pages 371-402 in Ruddiman, W. F., and H. E. Wright, Jr., eds. North America and adjacent oceans during the last deglaciation. The geology of North America, Vol. K-3. Geological Society of America, Boulder, Colorado.

Gray, B.S. 2002. An addition to the herpetofauna of the Asbury Woods Greenway, Erie County, Pennsylvania. Bulletin of the Chicago Herpetological Society 37:196-197.

Green, N.B., and T.K. Pauley. 1987. Amphibians and reptiles in West Virginia. University of Pittsburgh Press, Pittsburgh.

Gregory, P.T. 1977. Life history observations of three species of snakes in Manitoba. Canadian Field-Naturalist 91:19-27. 
Gregory, P.T. 2009. Northern lights and seasonal sex: The reproductive ecology of cool-climate snakes. Herpetologica 65:1-13.

Hankinson, T.L. 1917. Amphibians and reptiles of the Charleston region. Transactions of the Illinois State Academy of Science 10:322-330.

Hansel, A.K., and W.H. Johnson. 1996. Weldon and Mason groups: Lithostratigraphic reclassification of deposits of the Wisconsin Episode, Lake Michigan Lobe area. Illinois State Geological Survey Bulletin 104:1-116.

Harding, J.H. 1997. Amphibians and reptiles of the Great Lakes region. University of Michigan Press, Ann Arbor.

Heatwole, H., and L.L. Getz. 1960. Studies on the amphibians and reptiles of Mud Lake Bog in southern Michigan. JackPine Warbler 38:107-112.

Holliday, V.T., J.C. Knox, G.L. Running, IV, R.D. Mandel, and C.R. Ferring. 2002. The central lowlands and Great Plains. Pages 335-362 in Orme, A. R., ed. The physical geography of North America. Oxford University Press, New York.

Holman, J.A. 1992a. Patterns of herpetological re-occupation of post-glacial Michigan, amphibians and reptiles come home. Michigan Academician 24:453-466.

Holman, J.A. 1992b. Late Quaternary herpetofauna of the central Great Lakes region, U.S.A.: zoogeographical and paleoecological implications. Quaternary Science Reviews 11:345-351.
Holman, J.A. 1995. Pleistocene amphibians and reptiles in North America. Oxford University Press, New York.

Holman, J.A. 2000. Fossil snakes of North America, origin, evolution, distribution, paleoecology. Indiana University Press, Bloomington.

Holman, J.A., J.H. Harding, M.M. Hensley, and G.R. Dudderar. 1993. Michigan snakes, a field guide and pocket reference. Michigan State University Extension, East Lansing.

Hunter, M.L., Jr., J. Albright, and J. Arbuckle, eds. 1992. The amphibians and reptiles of Maine. The Maine Amphibian and Reptile Atlas Project. Maine Agricultural Experiment Station, Bulletin 838. University of Maine, Orono.

Hunter, M.L., Jr., A.J.K. Calhoun, and M. McCollough. 1999. Maine amphibians and reptiles. The University of Maine Press, Orono.

Kapfer, J.M. 2010. A survey of gravid snakes at several sites in southern Wisconsin. Reptiles \& Amphibians, Conservation and Natural History 17:22-25.

Kennicott, R. 1855. Catalogue of animals observed in Cook County Illinois. Transactions of the Illinois State Agricultural Society 1:577-595.

King, J.E. 1981. Late Quaternary vegetational history of Illinois. Ecological Monographs 51:43-62.

Klemens, M.W. 1993. Amphibians and reptiles of Connecticut and adjacent regions. State Geological and Natural History Survey of Connecticut Bulletin No. 112. 
Klimstra, W.D., and M. Hutchison. 1965. A collection of amphibians and reptiles in southern Illinois. Transactions of the Illinois State Academy of Science 58:152-157.

Lachner, E.A. 1942. An aggregation of snakes and salamanders during hibernation. Copeia 1942:262-263.

Lang, J.W. 1969. Hibernation and movements of Storeria occipitomaculata in northern Minnesota. Journal of Herpetology 3:196-197.

Lang, J.W. 1981. Hibernation and movements of Storeria occipitomaculata in northern Minnesota, summary. Page 9 in Elwell, L., K. Cram, and C. Johnson, eds. Ecology of reptiles and amphibians in Minnesota. Proceedings of a Symposium, March 13-15, 1981. Bald Eagle Outdoor Learning Center, Cass Lake, Minnesota.

Langlois, T.H. 1924. Notes on some Michigan snakes. Papers of the Michigan Academy of Science, Arts, and Letters 4:605-610.

Linzey, D.W. 1979. Snakes of Alabama. The Strode Publishers, Inc., Huntsville, Alabama.

Loomis, R.B., and J.K. Jones, Jr. 1948. New herpetological county records from central Minnesota. Herpetologica 4:213-214.

Ludwig, D.R., M. Redmer, R. Domazlicky, S.N. Kobal, and B. Conklin. 1990. A survey of amphibians and reptiles within the Forest Preserve District of DuPage County (1988-1990). Unpublished report prepared for the Forest Preserve District of DuPage County, Illinois.
McKinstry, D.M., and S. Felege. 1974.

Snakes of northwestern Pennsylvania. Bulletin of the Maryland Herpetological Society 10:29-31.

Meshaka, W.E., Jr., S.D. Marshall, T.J. Guiher, and L. Zemba. 2009. Grassland snake assemblages in central and western Pennsylvania and northeastern Ohio, USA. Herpetological Bulletin (110):8-19.

Minton, S., Jr. 1944. Introduction to the study of the reptiles of Indiana. American Midland Naturalist 32:438-477.

Minton, S., Jr., and J.E. Minton. 1948. Notes on a herpetological collection from the middle Mississippi Valley. American Midland Naturalist 40:378-390.

Mitchell, J. 1994. The reptiles of Virginia. Smithsonian Institution Press, Washington, D. C.

Munyer, E.A., and P.W. Parmalee. 1967. Additional herpetological records from Sangamon, Macoupin, and Menard counties, Illinois. Transactions of the Illinois State Academy of Science 60:200-202.

Neill, W.T. 1951. Amphibians and reptiles of a fifteen-acre tract in Georgia. American Midland Naturalist 45:241244.

Oldfield, B., and J.J. Moriarty. 1994. Amphibians \& reptiles native to Minnesota. University of Minnesota Press, Minneapolis.

Over, W.H. 1923. Amphibians and reptiles of South Dakota. South Dakota Geological and Natural History Survey Bulletin, Series XXIII, (10) 12:1-34. 
Over, W.H. 1943. Amphibians and reptiles of South Dakota. Revised 2nd ed., University of South Dakota Natural History Studies (6)1-31.

Palmer, W.M., and A.L. Braswell. 1995. Reptiles of North Carolina. The University of North Carolina Press, Chapel Hill.

Parmalee, P. 1955. Reptiles of Illinois. Illinois State Museum, Popular Science Series, Vol. 5. Springfield.

Peters, J. 1942. Reptiles \& amphibians of Cumberland County, Illinois. Copeia 1942:182-183.

Petzing, J.E., T.L. Esker, T. Buhnerkempe, and B.R. Edgin. 2009. Amphibian and reptile records from southeastern Illinois, USA. Herpetological Review 40:241-243.

Petzing, J.E., J.M. Mui, M.J. Dreslik, A.R. Kuhns, D.B. Shepard, C.A. Phillips, J.K. Tucker, J.K. Warner, D. Mauger, T.G. Anton, E.J. Gittinger, T.R. Hunkapiller, B.C. Jellen, and R.J. Cosgriff. 2007. Filling in the gaps II: new Illinois amphibian and reptile county records from 2000-2005. Herpetological Review 38:240-243.

Phillips, C.A., R.A. Brandon, and E.O. Moll. 1999. Field guide to amphibians and reptiles of Illinois. Illinois Natural History Survey Manual 8. Champaign.

Pielou, E.C. 1991. After the Ice Age, the return of life to glaciated North America. University of Chicago Press, Chicago.

Pope, C.H. 1964. Amphibians and reptiles of the Chicago area. Chicago Natural History Museum Press, Chicago.
Purdue, J.R., and W.J. Webb. 1986. Inventory of zoological collections fish, amphibian, and reptile skeletons. Inventory of the Collections No. 1, Part 6, Illinois State Museum, Springfield.

Redmer, M., and S.R. Ballard. 1995. Recent distribution records for amphibians and reptiles in Illinois. Herpetological Review 26:49-53.

Rhodes, R.S., II. 1984. Paleoecology and regional paleoclimatic implications of the Farmdalian Craigmile and Woodfordian Waubonsie mammalian local faunas, southwestern Iowa. Report of Investigations No. 40, Illinois State Museum, Springfield.

Robertson, K.R., R.C. Anderson, and M.W. Schwartz. 1997. The tallgrass prairie mosaic. Pages 55-87 in Schwartz, M. W., ed. Conservation in highly fragmented landscapes. Chapman \& Hall, New York.

Rowe, K., E. Heske, P. Brown, and K. Paige. 2004. Surviving the ice: Northern refugia and postglacial colonization. Proceedings of the National Academy of Sciences 101:10355-10359.

Ruthven, A.G. 1906. The cold-blooded vertebrates of the Porcupine Mountains and Isle Royale, Michigan. Reports of the State Board of Geological Survey 1905:107-112.

Sabaj Pérez, M., ed. 2010. Standard symbolic codes for institutional resource collections in herpetology and ichthyology: an online reference. Version 2.0 accessible at http:// www.asih.org/, American Society of Ichthyologists and Herpetologists, Washington, DC. 
Schmidt, K.P. 1938. Herpetological evidence for the postglacial eastward extension of the steppe in North America. Ecology 19:396-407.

Schmidt, K.P., and D.D. Davis. 1941. Field book of snakes of the United States and Canada. G. P. Putnam's Sons, New York.

Schmidt, K.P., and W.L. Necker. 1935. Amphibians and reptiles of the Chicago region. Bulletin of the Chicago Academy of Sciences 5:5777.

Semlitsch, R.D., and G.B. Moran. 1984. Ecology of the redbelly snake (Storeria occipitomaculata) using mesic habitats in South Carolina. American Midland Naturalist 111:3340.

Sliwinski, R. 1990. Storeria occipitomaculata occipitomaculata. Herpetological Review 21:97.

Smith, H.M. 1963. The identity of the Black Hills population of Storeria occipitomaculata, the red-bellied snake. Herpetologica 19:17-21.

Smith, P.W. 1957. An analysis of postWisconsin biogeography of the prairie peninsula region based on distributional phenomena among terrestrial vertebrate populations. Ecology 38:205-218.

Smith, P.W. 1961. The amphibians and reptiles of Illinois. Illinois Natural History Survey Bulletin 28:1-298

Smith, P.W., and S.A. Minton, Jr. 1957. A distributional summary of the herpetofauna of Indiana and Illinois. American Midland Naturalist 58:341351.
Stein, H.A. 1954. Additional records of amphibians and reptiles in southern Illinois. American Midland Naturalist 51:311-312.

Stille, W.T., and R.A. Edgren, Jr. 1948. New records for amphibians and reptiles in the Chicago area, 1939-1947. Bulletin of the Chicago Academy of Sciences 8:195-202.

Storer, D.H. 1839. Reptiles of Massachusetts. Pages 207-253 in Emerson, G.B., ed. Reports of the fishes, reptiles and birds of Massachusetts. Dutton and Wentworth, State Printers, Boston.

Stuart, A.J. 1979. Pleistocene occurrences of the European pond tortoise (Emys obicularis L.) in Britain. Boreas 8:359-371.

Tennant, A., K.L. Krysko, and R.D. Bartlett. 1997. A field guide to snakes of Florida. Gulf Publishing Company, Houston.

Tennant, A., G.T. Salmon, and R.B. King. 2003. Snakes of North America, eastern and central regions. Revised edition. Lone Star Books, Lanham, Maryland.

Thurow, G.R. 1999. Herpetofaunal changes in McDonough County, Illinois. Transactions of the Illinois State Academy of Science 92:147-161.

Thurow, G.R., and R.P. Sliwinski. 1991. Herpetological distribution records from Illinois. Bulletin of the Chicago Herpetological Society 26:129-132.

Transeau, E.N. 1935. The prairie peninsula. Ecology 16:423-437.

Trapido, H. 1944. The snakes of the genus Storeria. American Midland Naturalist 31:1-84. 
Tucker, J.K., R.J. Maher, and J.B. Hatcher. 1994. Storeria occipitomaculata occipitomaculata. Herpetological Review 25:35.

Walley, H.D. 2001. Storeria occipitomaculata. Herpetological Review 32:125.

Weed, A.C. 1922. Reptile notes. Copeia (112)84-87.

Werler, J.E., and J.R. Dixon. 2000. Texas snakes, identification, distribution, and natural history. University of Texas Press, Austin.

Willman, H.B., and J.C. Frye. 1970. Pleistocene stratigraphy of Illinois. Illinois State Geological Survey Bulletin 94:1-204.

Wilson, A.K. 1999. New Illinois amphibian and reptile distribution records from the Kaskaskia River drainage. Herpetological Review 30:118-120.

Wodika, B.R. 2008. Storeria occipitomaculata. Herpetological Review 39:112-113.

Wright, A.H., and A.A. Wright. 1957. Handbook of snakes of the United States and Canada. Vol. 2. Comstock Publishing Associates, Cornell University Press, Ithaca, New York.

Wright, H.E., Jr. 1987. Synthesis: the land south of the ice sheets. Pages 479-488 in Ruddiman, W. F., and H. E. Wright, Jr., eds. North America and adjacent oceans during the last deglaciation. The geology of North America. Vol. K-3, Geological Society of America, Boulder, Colorado. 


\section{Appendix}

List of specimens examined. Each number represents one specimen and all specimens, except three skeletons and one photographic slide, were preserved in alcohol.

Alexander County - INHS 7839; 8152; 8742; 11361. Bond County - INHS 86558658. Carroll County-SIUC 2210. Clark County-INHS 18495. Clay County-INHS 9825. Coles County -EIU four unnumbered specimens; INHS 6121; 7746. Cook CountyCA 121-124; 6106-6108; 6176; 6686-6688; 6725-6746; 6746A-6786; 7923-7937; 13712; 16558-16562; 17132; 18471; 18709-18710; 18900-18903; CA-NU 2968-2969; CU 3408; FMNH 2972-2973; 3289; 15698; 15812; 18052-18064; 19317; 19399; 33785-33786; 41263; 60554; 67387; 98593-98594; 109928; 154939-154960; 154962-154968; 154970; 155006-155007; 164468-164508; 203966; 204604-204605; 252991; 262514-262515; 263456; 268565; HDW-NIU 617; INHS 12286-12287; 13027; 14284; 15703; 16867; 17790; 19488-19489; 20253; MCZ 3274; 178227; UIMNH 1172; USNM 132902. Cook County-Lake County Line-FMNH 22837; 135168-135169; 154969. Crawford County-INHS 19954. Cumberland County-INHS 1941. DeKalb CountyHDW-NIU 1927-1929. DuPage County-CA 6950-6953; 6963-6965; FMNH 35080; 3531735318; 38125; INHS 5403-5404. Effingham County-INHS 8272; 19464; 20044. Fayette County-INHS 18050. Fulton CountyINHS 19508. Hancock County-INHS 2652; TCWC 20753. Jackson County-INHS 8354; SIUC 142; 674; 1266; 1764; 2105; 2261; 3455; 4095; 4241; 4271; UMMZ 100422.
Jefferson County－LSUMZ 77975. Jersey County - INHS 10989; PC 521-522; SIUC 2473. Johnson County-INHS 21135; SIUC 2873. Knox County-INHS 10877; 15759; 17232. Lake County_FMNH 11403; 31941; $33890 ; 38233 ; 57447 ; 135167 ; 135170$ 135174; 154971; 229507; 229522; 229524; 261829; 262540-262541; INHS 16849; 17943. Macoupin County-INHS 14865; ISM 622011. McHenry County-FMNH 229506; INHS 11860; 11898-11899; 14271; 1554915550. Menard County - ISM 622390; MCZ 5583. Peoria County-INHS 7684; 15735. Piatt County - INHS 2867; 5192; 5256; 7752; 8511; 18913. Pike County-UIMNH 50849. Pope County - INHS 1572-1574; 5457; SIUC 297. Randolph County-ISM 688486. Richland County - USNM 37973; 38415-38418; 49716. Rock Island CountyHDW-NIU 1788. Sangamon County-ISM 622095. Shelby County - INHS 20943. St. Clair County-USNM 8772; 8775-8776; 8990; 524387-524391. Tazewell CountyISUC 1850. Union County-FMNH 23716; INHS 5331-5332; 3927; 5833; LSUMZ 7267; SIUC 160; 163; 2498; 2528; UMMZ 100263. Wabash County－USNM 12022; 12022 (524392); 12022 (524393). Washington County-INHS 14079. Will CountyINHS 8482; 11284; 11476; 13482; 17785. Williamson County -SIUC 2103. Southern Illinois ("multiple counties") - USNM 7284; 524386. Illinois-AMNH 2788. 

RESEARCH INSTITUTE

Illinois Natural History Survey

Forbes Natural History Building

1816 South Oak Street

Champaign, Illinois 61820

217-333-6880 